$$
\begin{aligned}
& \text { اثر عصاره بيضهُ كوسفند در رشد فوليكولهاى مو و ترميم زخم يوست موش صحرايى نز نزاد ويستار } \\
& \text { نسترن سهر ابى فر '، جواد بهار آرا'ا“، ناصر مهلدوى شهرى'، سعيده ظفر بالا نزاد'، الهه امينى }
\end{aligned}
$$

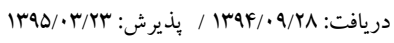

$$
\begin{aligned}
& \text { اكروه زيستشناسى سلولى تكوينى جانورى،دانشكده علوم، دانشگاه آزاد اسلامى واحد مشهد، مشهد }
\end{aligned}
$$

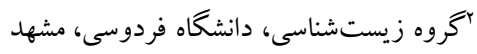

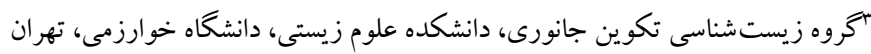

baharara@mshdiau.ac.ir : مسئول مكاتبات

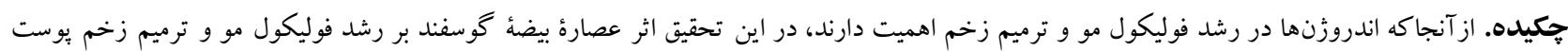

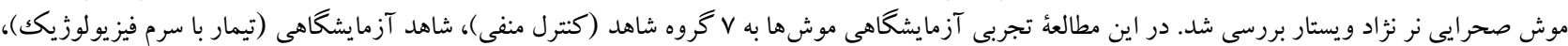

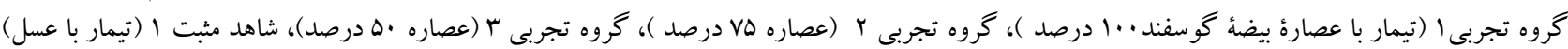

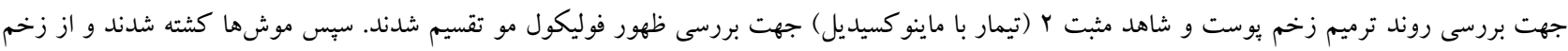

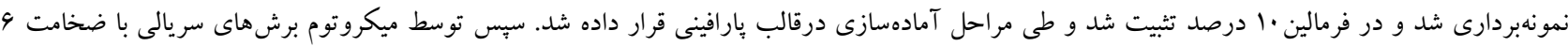

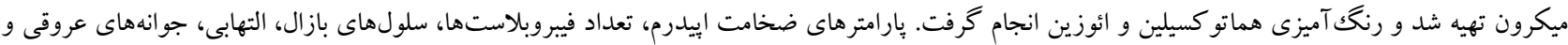

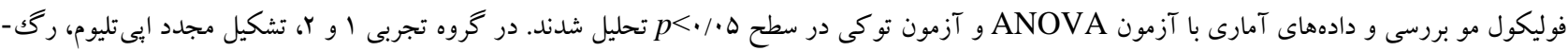

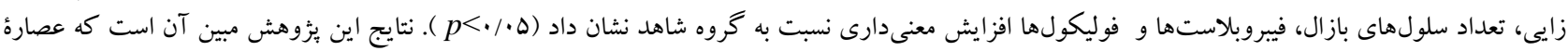

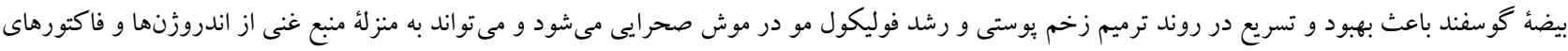
رشد ييشنهاد مناسب در مطالعات ترميمى بالينى باشد.

$$
\text { وازههاى كليدى. گناد نر، ماينو كسيديل، اندروزن، التيام، فيبروبلاست }
$$

\title{
The impact of sheep testis extract on hair follicle growth and skin healing of Wistar rats
}

\author{
Nastaran Sohrabifar ${ }^{1}$, Javad Baharara ${ }^{\mathbf{1}^{*}}$, Naser Mahdavi Shahri ${ }^{2}$, Saeede Zafar Balanejad ${ }^{1}$, Elaheh \\ $\mathrm{Amini}^{3}$
}

Received: 18/12/2015 / Accepted: 12/06/2016

${ }^{1}$ Department of Animal Development Biology, Faculty of Science, Islamic Azad University, Mashhad, Iran

${ }^{2}$ Department of Biology, Ferdowsi University, Mashhad, Iran

${ }^{3}$ Department of Animal Biology, Faculty of Biological Sciences, Kharazmi University, Tehran, Iran

"Correspondent author: baharara@mshdiau.ac.ir

\begin{abstract}
Androgens have been proved to have positive effect on hair follicle growth and wound healing; therefore this study was aimed mainly to evaluate the impact of sheep testis extract on the improvement and growth of hair follicle as well as recovery of injuries on the skin of Wistar rats. In this experimental study, rats were randomly divided into 7 groups: control (negative control), sham (treatment with physiologic serum), experimental group 1 (treatment with $100 \%$ sheep testis extract), experimental group 2 (treatment with $75 \%$ extract), experimental group 3 (treatment with $50 \%$ extract), positive control 1 (treatment with honey for evaluation of wound healing) and positive control 2 (treatment with Minoxidil for evaluation of hair follicle growth). Then, rats were killed and the removed approximate wound skin was fixed in 10\% formalin, kept in paraffin block. In addition, the serial sections with $6 \mu$ m thickness were prepared and hematoxylin eosin staining was performed. Then, epidermal thickness, the number of fibroblast, basal cells, inflammatory cells, vessel bud and hair follicle were assessed. Statistical analysis was performed by one way ANOVA, Tukey test at $p>0.05$. The results showed that the wound healing process, the hair follicle formation, the reepithelialization, the angiogenesis, the number of basal cell, fibroblasts, and the number of follicles were significantly improved in the experimental groups 1 and 2 (in comparison with control group ( $p>0.05$ ). Results of this study demonstrated that the sheep testis extract induced improvement in regeneration process, wound healing and hair follicle growth in rats, which can be suggested as a suitable candidate for clinical wound healing studies due to its richness of androgen and growth factors.
\end{abstract}

Keywords. male gonad, minoxidil, androgen, healing, fibroblast 
مطلب است كه بين كهولت سن، ترميم زخم و ترشح اندروزنها

ارتباط مستقيمى وجود دارد (Ashcroft, 2004).

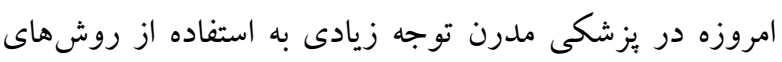
درمانى با مواد طبيعى و بيولوزيكك شده است و در اين راستا

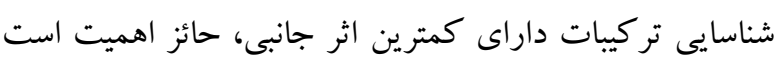

.(Golshan et al., 2016)

عصارةٌ بيضه داراى مقادير زيادى بتاسيم، تستوسترون، تركيبات

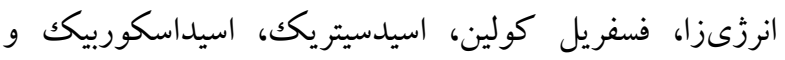

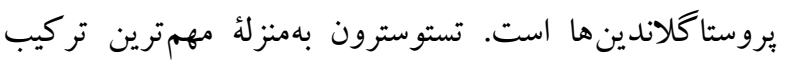

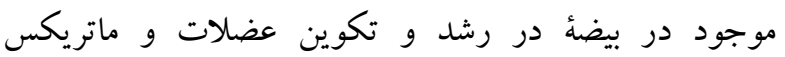
استخوانها، ساخت اولئ بافتها، بازسازى سلولهاى عصبى و ضiامت يوست بدن نقش دارد ( ) Ashcroft \& Mills, 2002). با توجه به وجود تركيبات اندروزنى در بافت بـ بيضه درد يزوهش حاضر اثر عصارة بيضئ كوسفند بر ترميم زخم يوستى و

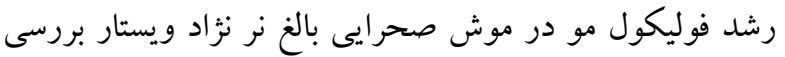

اين يُزوهش تجربى آزمايشكاهى در سال سوسا در مركز تحقيقات بيولوزى كاربردى تكوين جانورى دانشكاه آزاد واحد

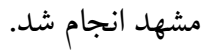

\section{روش تهية عصار هُ بيضهُ كوسفند}

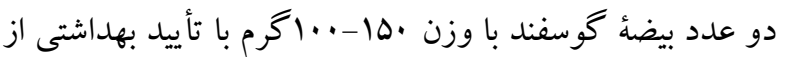
كشتار گاه مشهد تهيه شد. بِ بساز شستوشوى بيضهها، اين اندام

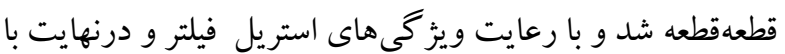

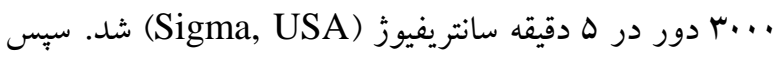
بخش رويى محلول بهعنوان عصارة تام بيضه در دماى F درجه

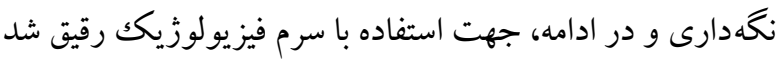

.(Eisenegger et al., 2013)

تيمار حيوانات. در اجراى اين يُزوهش از موش صحرايى نزاد ويستار استفاده شد. 9ه سر موش صحرايى نزاد ويستار جنس نر

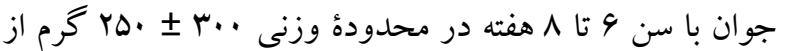
مؤسسه سرمسازى رازى مشهد تهيه و بهمدت يككهفته قبل از شروع آزمايشها در دماى مطلوب، با رزيم غذايى متداول، جرخهُ Y I ساعت روشنايى و Ir ساعت تاريكى در اتاق
مقدمه

مو از نظر حفاظتى عملكردهاى بيولوزيكى متفاوتى دارد بهنحوى كه بيماران مبتلا به ريزش مو يا رشد بيشاز حد مو در

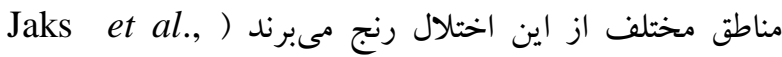

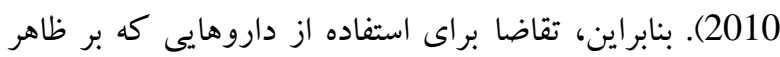

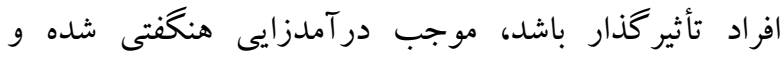

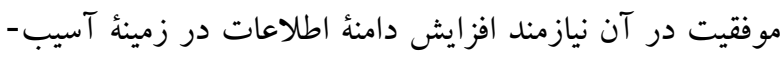
شناسى مو است (Léguillier et al., 2015). در ايجاد

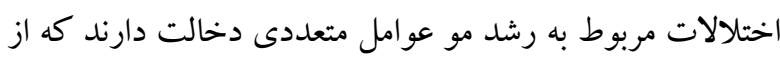

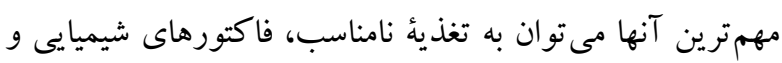

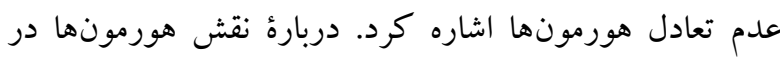
اختلالات رشد و نمو مو مىتوان تأكيد بيشترى بر اندروزنها دمانها

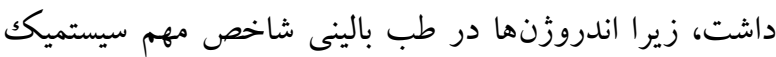
كنترل دارويى در رشد مو بهشمار مىروند (Sarabahi, 2012). هورمونهاى جنسى نظير استروزن و تستوسترون بهسبب وجود

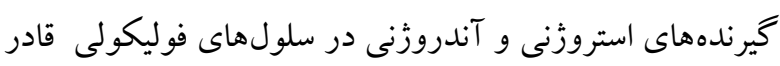

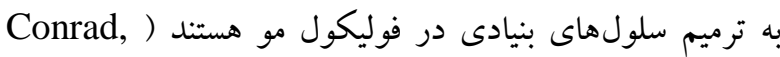
. (2008 روند ترميم زخم كه محققان يزشكى و فيزيولوزى به آن توجه

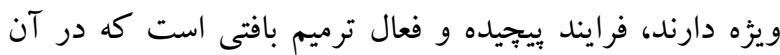
بسيارى از وقايع سلولى و مولكولى شامل سه فاز: التهاب، تشكيل بافت و بازآرايى بافت كه با يكديخر هميوشانى زمانى دارند

.(Bates et al., 2005)

كام اول در بهبود زخم، ترميم و جلو گيرى از برهمخوردن تعادل مايعات بدن براى محدود كردن هجوم باتوزنها است ( Pazyar

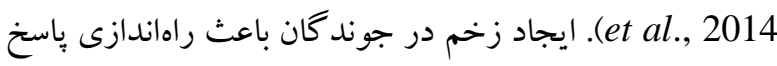
ايمنى سريعى مىشود كه سلولهاى بسيارى در اين واكنش فعال هستند (Shirzad et al., 2010). تحقيقات بسيار گستردهاى دربارة درمان زخم انجام شده است و روشهاى مختلفى براى

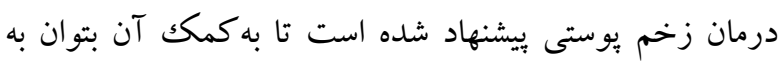

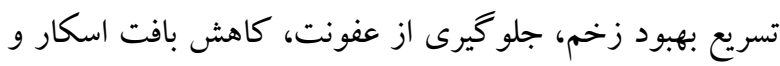
جلو گيرى از ناتوانى بيمار دست يافت ) ( Chen \& Chuong,

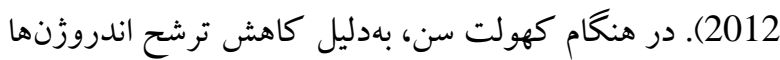

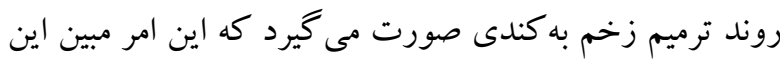


عروق و فوليكول مو بهوسيلة ميكروسكوٍِ نورى ( Olympus, (Japan بررسى شد (Sato et al., 2011).

\section{يارامترهاى ميكروسكويى تحت ارزيابى در آزمايش}

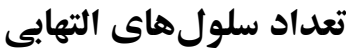

سلولهاى آماسى نشانهُ التهاب در زخم هستند و التهاب يكى از فاكتورهاى مهم در ترميم زخم است، ازاينرو ما تعداد اين

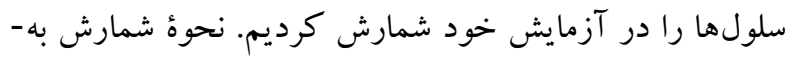
اينترتيب بود كه از هر زخم ع برش و از هر برش ب ناحئ

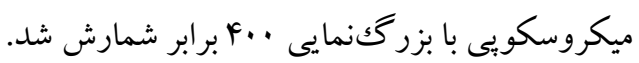

\section{تعداد سلولهاى فيبروبلاست}

سلولهاى فيبروبلاست نقش مهمى در ترميم زخم دارند. اين سلولها به محل زخم مهاجرت كرده و در آنجا كلازن سنتز و ترشح مى كنند كه در بستهشن زخم نقش اساسى دارد. براى شمارش اين سلولها همانند سلولهاى التهابى عمل شد؛ يعنى از

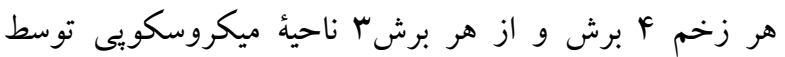

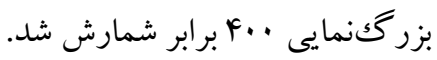

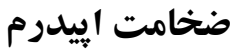

إيدرم لائٔ رويوست است كه اندكى بعد از ايجاد زخم با مهاجرت سلولى اقدام به بسته شدن زخم مى كند. در اين

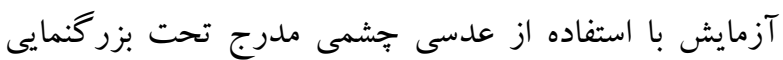
F... برابر ضخامت إيدرم (ضخامت إيدرم برحسب ميكرومتر)

براى هر زخم اندازهيرى شد (Rezaii et al., 2008 ).

\section{ركتزايى}

از ديخر عوامل مهم در ترميم زخم رگتزايى و ايجاد شبكة جديد ركى در محل زخم است. براى بررسى اين بارامتر

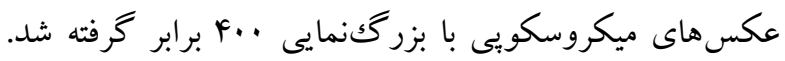

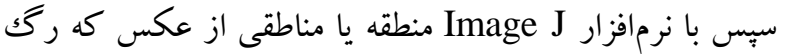
در آنها ديده مىشد شمارش شد. بدين ترتيب، ميزان ركتزايى

در هر زخم دقيقتر مشخص شد (Sato et al., 2011).
حيوانات در قفسهاى شفاف و موقعيت استاندارد نخهدارى شدند. غذاى بهصورت حبههاى آماده در اختيار آنها قرار داده شد و آب لازم از آب لوله كشى شهر تأمين شد. موشها درگروههاى شاهد (كنترل منفى يا بدون تيمار)، شاهد

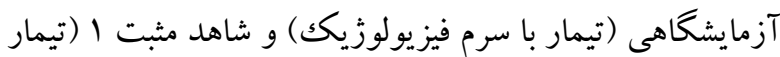

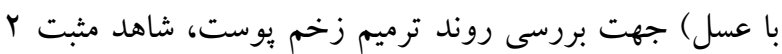

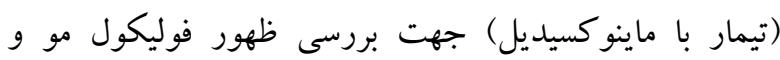
كروههاى تجربى اوبوَّ بهترتيب تيمار شدند با عصارة بيضة

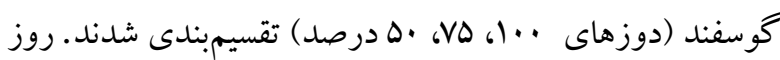
جراحى روز صفر محسوب شد و بهمدت هفتروز، هر روز r مرتبه تيمار در زمان مشخص انجام شد.

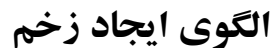

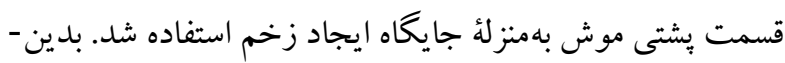

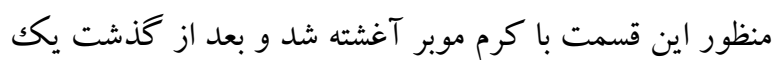

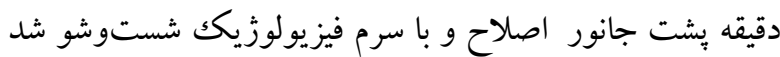

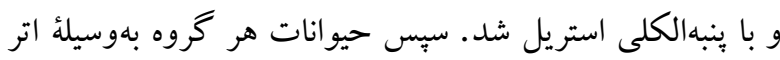

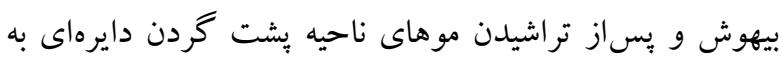

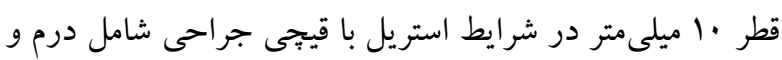

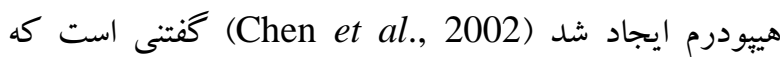
زخمها نزديكك به ناحئ سر ايجاد شدند تا جانور نتواند زخمها را بيند (Golpour et al., 2013).

\section{نمونهبردارى، برش كيرى و رنكى آميزى اختصاصى}

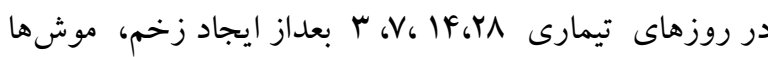

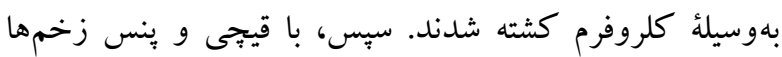
برداشته و از بدن جانور جدا شدند و با نرمال سالين شستوشو داده شدند. در مرحلةُ بعد نمونهها به كمكك فيكساتور بوئن تثبيت و آب گيرى و توسط ميكروتوم (Diapath, Italy)، برشهاى

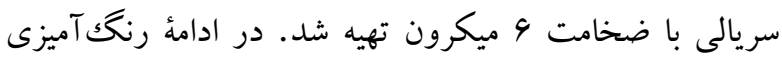

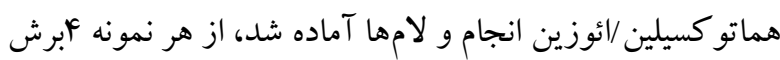

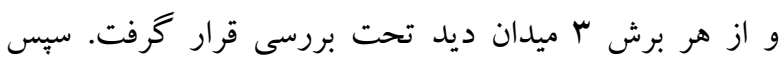
ضخامت إيدرم، سلولهاى التهابى و فيبروبلاست، سلول بازال، 
ارزيابى آمارى نشان داد كه ميزان تراكم منطقهاى در همه

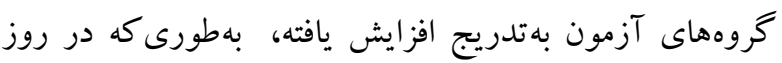
هفتم، به بيشترين مقدار خود رسيد. در اين روز بيشترين مقدار

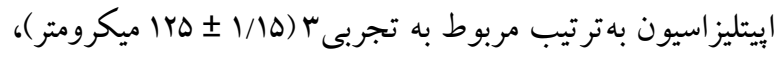

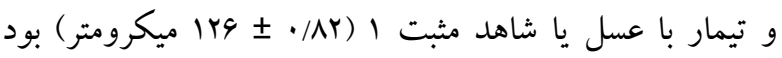

$$
\text { . }(p<\cdot / \cdot \cdot 1)
$$

درصورتى كه در بقيئ گروهها اختلاف معنادارى مشاهده نشد. از

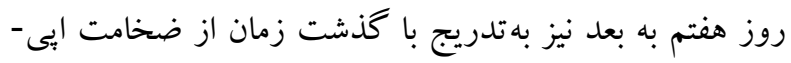

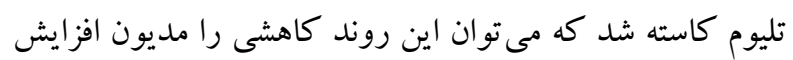
فاصلهاى داشت كه سلولهاى مهاجر طى كرده بودند ( Baum, 2005)، اين درحالى است كه در روز جهاردهم اندازه ضخامت ايى تليوم به ضخامت بوست طبيعى نزديكك شد.

بررسى هاى صورت گرفته در روند ترميم زخم بيانگر اين مطلب است كه ميانكين ضخامت إبى تليوم در روز جهاردهم در گروره

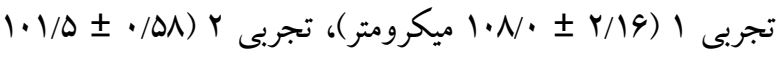

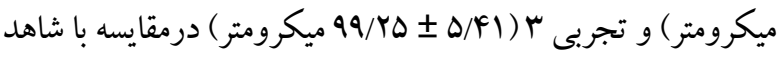

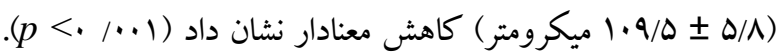
در روز بيست و هشتم كاهش معنىدار در ميانگين ضخامت

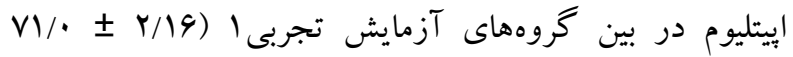
ميكرومتر) و تجربى ( نسبت به گروه شاهد يا كنترل منفى ( (مG/Va \pm I/ra)

\section{بررسى تعداد سلولهاى بازال}

بررسى تعداد سلولهاى بازال در روز سوم نشان داد كه در

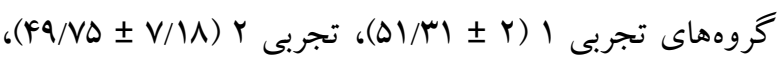

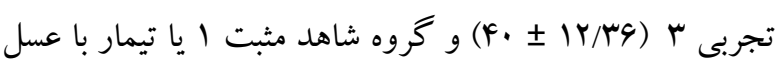

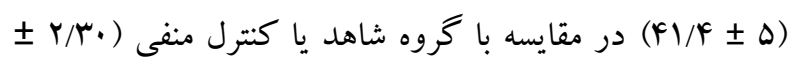

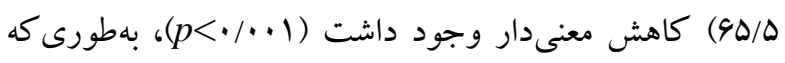

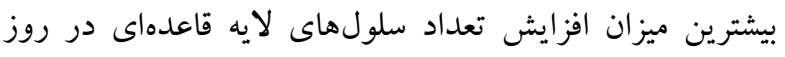

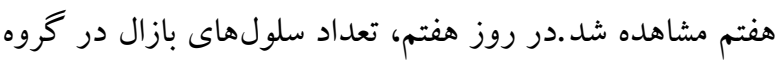

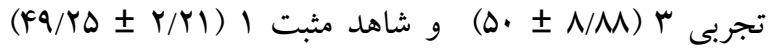
مشاهده شد كه افزايش معنىدارى در حد |..| •> p نسبت به كروه شاهد (Fr/VD

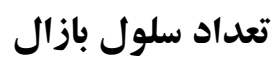

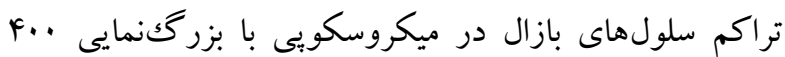
برابر شمارش شد. براى شمارش اين سلولها هماند سلولهاى بلد التهابى عمل شد (Rezaii et al., 2008).

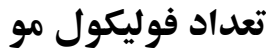

تعداد فوليكولهاى مو در ميكروسكويى با بزر خنمايى ..F برابر

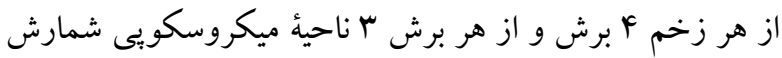
شد. (Rezaii et al., 2008).

\section{شمارش سلولها}

بررسى ميانگين ضخامت إيدرم، تعداد سلول بازال، سلول

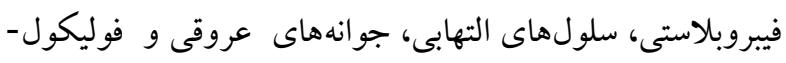
هاى مو در برشهاى بافتى مربوط به گروههاى شاهد (كنترل

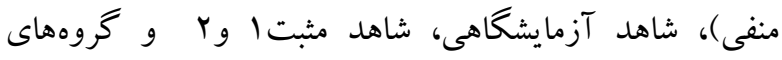

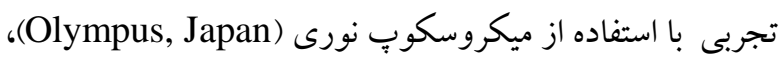

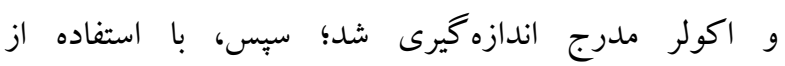

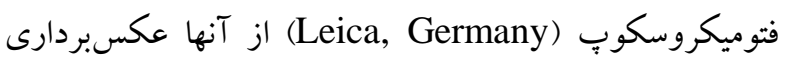
صورت گرفت (Okita et al., 2007).

\section{تجزيه و تحليل آمارى}

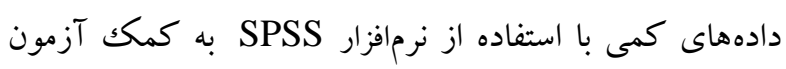

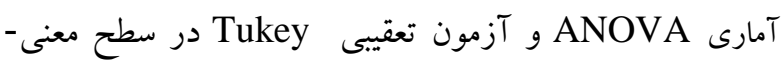

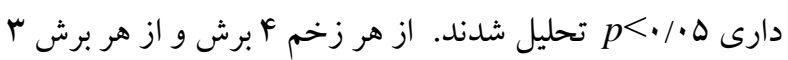

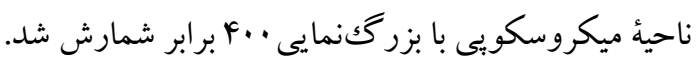

\section{يافتهها}

\section{نتايج بررسى إيتليزاسيون}

در روز سوم، ايىتليالىشدن ناحئ زخم تحت بررسى قرار

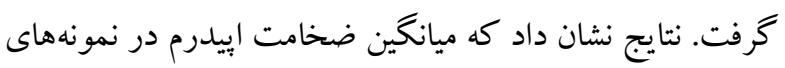

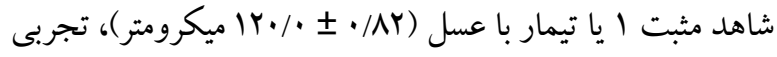
r

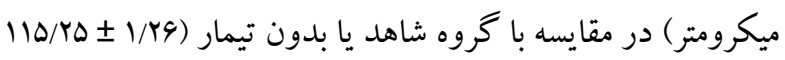

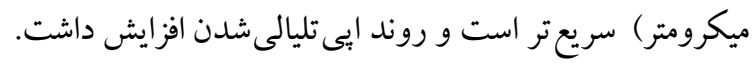



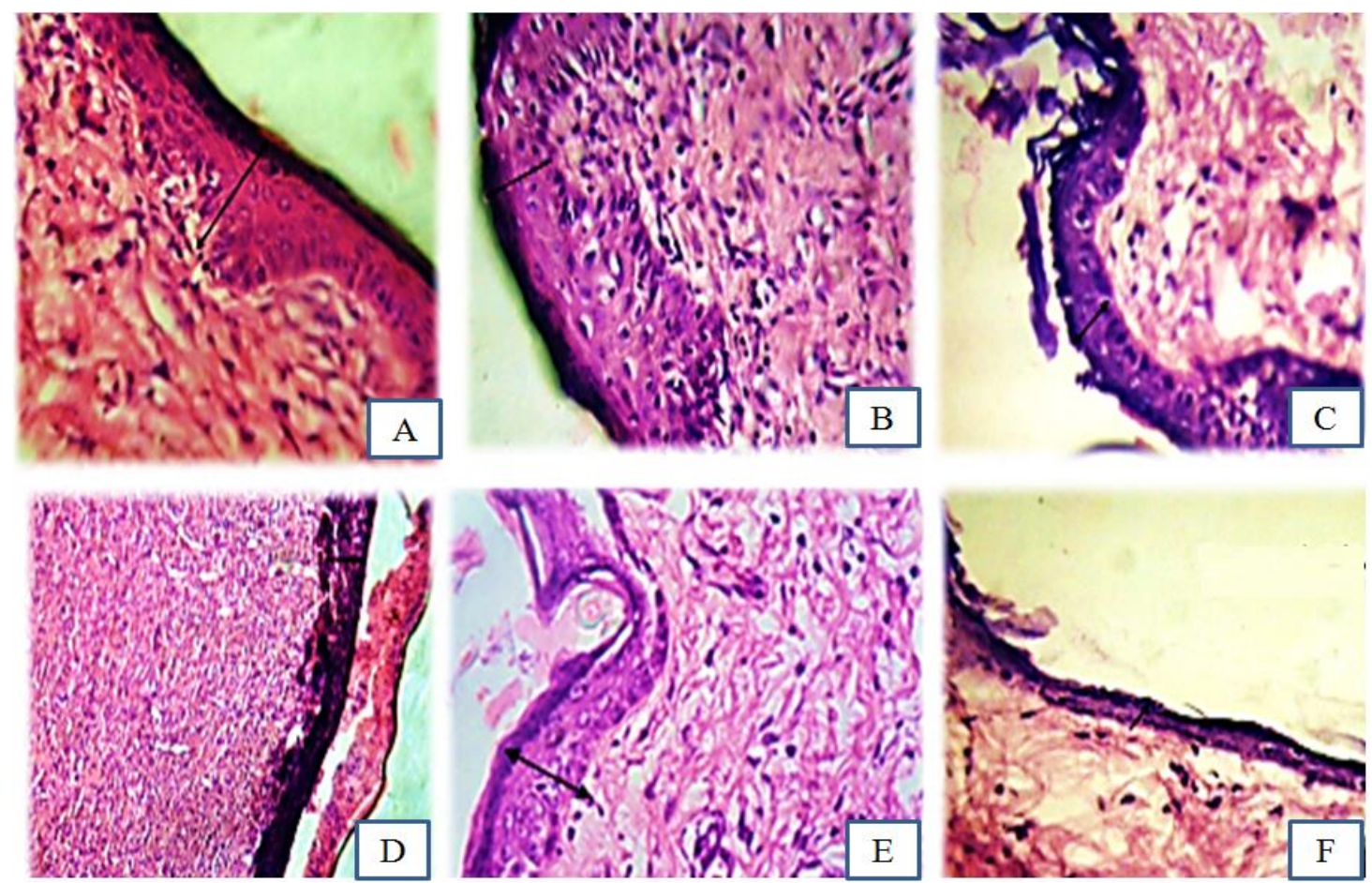

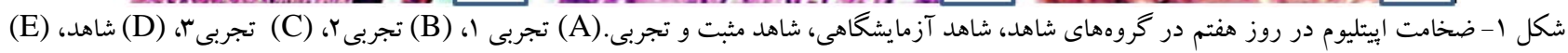

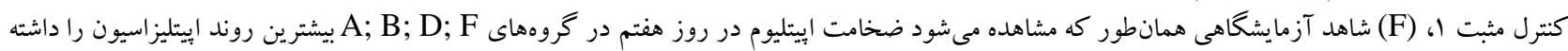

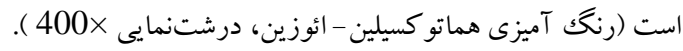

Fig. 1. The thickness of the epithelium on the seventh day of treatment in the control, sham, positive control and experimental groups. A) Experimental 1, (B) Experimental 2, (C) Experimental 3, (D) control, (E) positive control 1, (F) sham, as shown in the figre, the thickness of the epithelium on the seventh day in group A; B; D; F had the highest epithelialization process (H \& E staining. Magnification 400×.

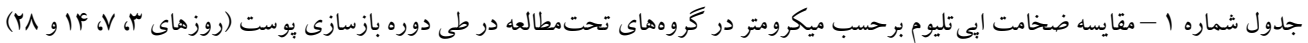

Table 1. Comparison of epithelium thickness in experimental groups during skin regeneration period (3, 7, 14, 28 days) on the basis of micrometer.

\begin{tabular}{|c|c|c|c|c|c|c|c|}
\hline & شاهد & سرم سرم & عسل & $\Delta . \%$ & $v Q \%$ & $\%$ & $p$ \\
\hline ضخامت ايتيلومج" & $11 \Delta / T \Delta \pm 1 / R q$ & $119 / \cdot \pm \cdot / \mathrm{Nr}$ & $\mid r \cdot / \cdot \pm \cdot / A r$ & $119 / 1 \Delta \pm \pm 1 / 49$ & $11 N \Delta \pm 1 / r 9$ & $119 \pm r / 19$ &.$/ .14$ \\
\hline ضخامت ايتيوم/ V & $119 N \Delta \pm . / 99$ & $\| N \cdot \pm \cdot / A r$ & $\mid r q / \cdot \pm \cdot / A r$ & $\| V / T \Delta \pm|N|$ & $N \cdot N \Delta \pm \cdot / 99$ & $1 r \Delta \pm 1 / 1 \Delta$ & $\cdot \cdots$ \\
\hline ضخامت ايتليوم If & $1.9 / \Delta \pm \Delta / \Lambda$ & $11 \cdot N \Delta \pm Y / \Delta$ & ৭৭/VD $\pm 1 / Y q$ & $1 \cdot N \cdot \pm r / 19$ & $1 \cdot 1 / \Delta \pm \cdot / \Delta \Lambda$ & $Q Q / r \Delta \pm \Delta / 41$ & $\%$ \\
\hline ضخامت إيتليوم/Y & $V G N \Delta \pm 1 / T \Delta$ & $V \in / r \Delta \pm 1 / V$ & $9 / \cdot \pm|/| q \mid$ & $V I / \cdot \pm r / 19$ & $V \cdot / r \Delta \pm r / r I$ & $q \mu / r \Delta \pm r / 1$ & $\% \cdots$ \\
\hline
\end{tabular}

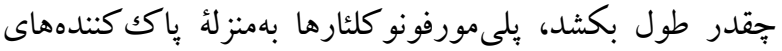
اوليه ايفاى نقش مى كنند كه بقاياى سلولى، ذرات خارجى و باكترى ها را حذف مى كنند.

مونوسيت در كردش مدت كوتاهى بعد از اين سلولها به محل زخم وارد مىشود، جايى كه فعال مىشود و ماكروفاز را تغيير مىدهد. اين سلولها نيز عملى مشابه يلى مورفونو كلئارها دارند. ولى زمان اوج تعداد آنها بين YA تا VY ساعت است كه ممكن است روزها تا هفتهها باقى بمانند. در طى دوره آزمايش حداكثر تكثير ماكروفازها در روز سوم در همه كروهها مشاهده
مقايسه ميانگين سلولهاى بازال در روز جهاردهم و روز بيست و

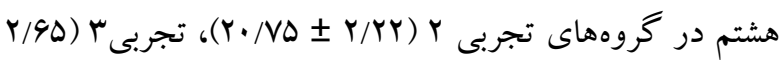
(1/19V I حد (1) بررسى تعداد سلول التهابى سلولهاى يلى مورفونو كلئار اولين سلولهاى التهابى هستند كه به جايگاه زخم يوستى مىرسند. در زخمى كه آلوده نشده باشد، دوره زمانى باقىماندن اين سلولهاكوتاه است و ييك جمعيتهاى آنها بين YF تا FA ساعت است. در اين زمان، هر 

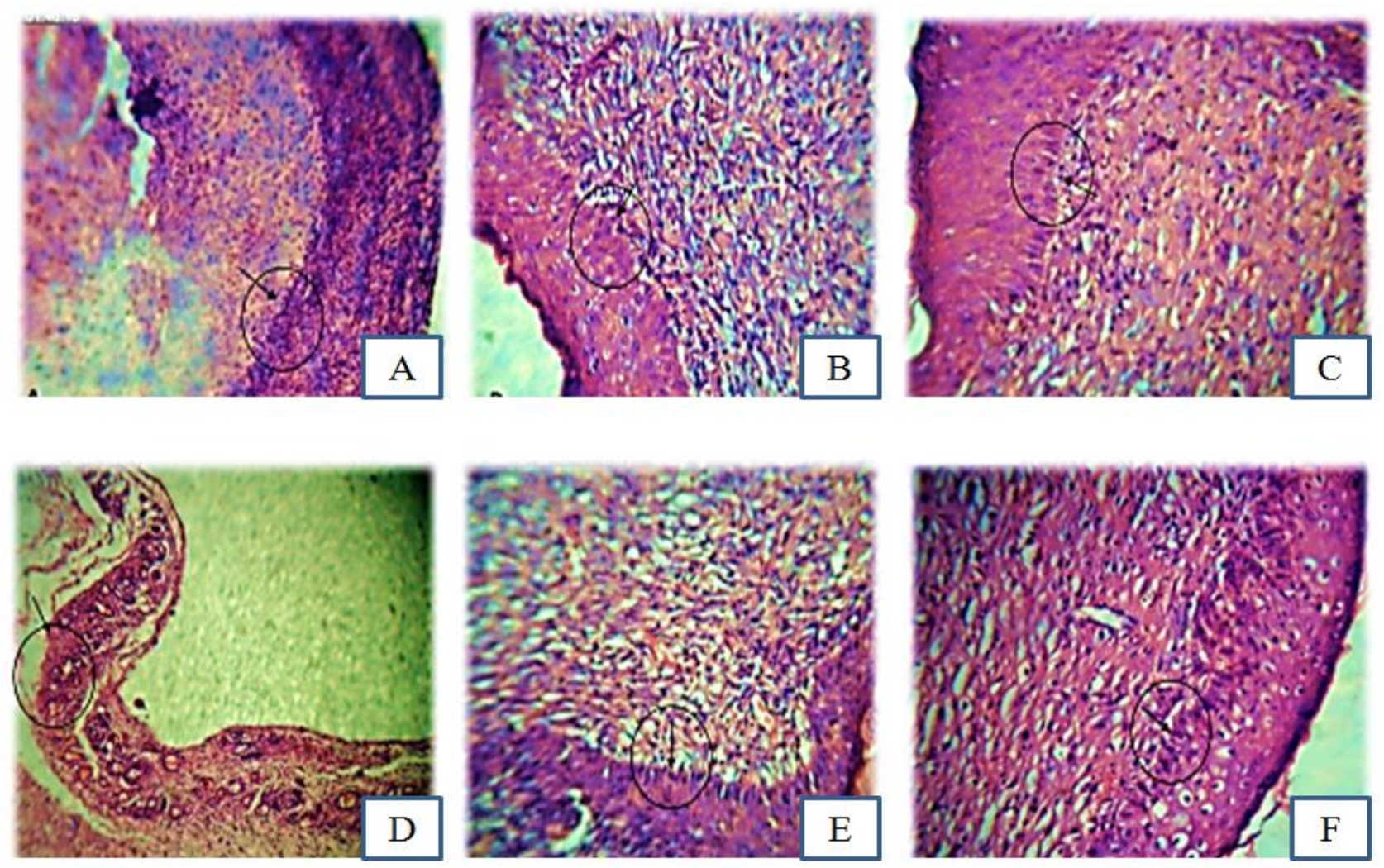

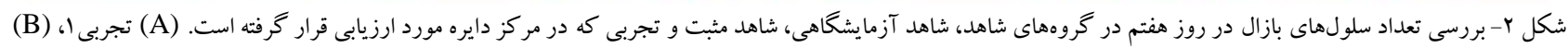

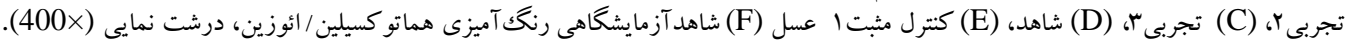
Fig. 2. Evaluation of basal cell number on the seventh day of treatment in the control, sham, positive control and experimental groups at the center of the circle. (A) Experimental 1, (B) Experimental 2, (C) Experimental 3, (D) control, (E) positive control 1 honey (F) sham which were stained with H \& E method. Magnification 400x.

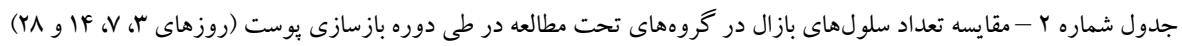

Table 2. Comparison the number of basal cells in the experimental groups during skin regeneration period (3, 7, 14, 28 days).

\begin{tabular}{|c|c|c|c|c|c|c|c|}
\hline & شاهد & سرم & عسل & $\Delta \cdot \%$ & $\mathrm{~V} \Delta \mathrm{O} \%$ & $1 . . \%$ & $p$ \\
\hline سلول بازال روز r & $9 \Delta / \Delta \pm Y \mu$. & $\Delta q / 1 \cdot \pm r / 19$ & $F \mid \wedge \Delta \Delta$ & $\Delta / N I \pm Y$ & $k q / v \Delta \pm V / M \Lambda$ & $F \cdot \pm I r / 4$ &.$\cdot \cdot r$ \\
\hline v v بلول بازال روز & $\mu N N \Delta \pm r / N$ & $r \Psi / r \Delta \pm \Psi K$. & $\mid q q / r \Delta \pm r / r)$ & $M I \pm r M V$ & $r r / r \Delta \pm \psi r / . r$ & $\Delta \cdot \pm N M$ & $\cdot \cdots$ \\
\hline سلول بازال روز IF & $r \cdot N \Delta \pm I M$ & $r V N \Delta \pm|N|$ & $\mid 9 \pm \cdot / 11$ & $Y Y / \Delta \pm Y / \cdot \Lambda$ & $r \cdot N \Delta \pm Y / Y Y$ & $W 9 N \pm Y / 9 D$ & $\cdot / \cdots$ \\
\hline سلول بازال روزيجم & $Y I / T \Delta \pm Y / Y \Delta$ & $19 / N \Delta \pm Y / .9$ & $\mid r / T \Delta \pm 1 / r \Delta$ & $M V \Delta \pm Y / \mid$ & $\mid f / r \Delta \pm 1 / \Delta$ & $I Y N \Delta \pm Y / Y Y$ & $.1 \times 49$ \\
\hline
\end{tabular}

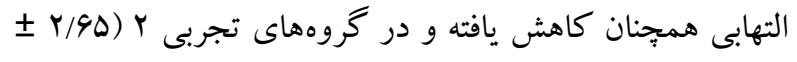

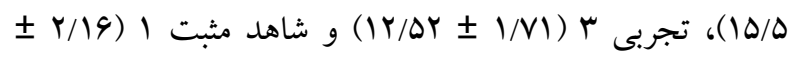

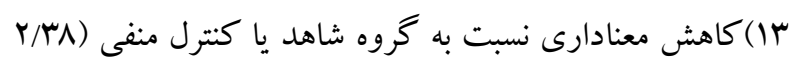

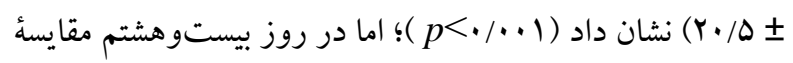

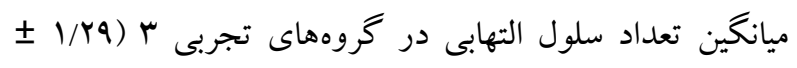

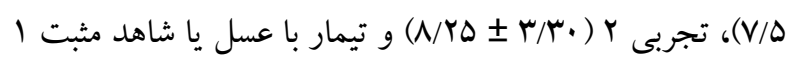

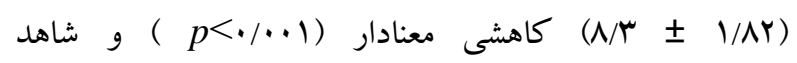
آزمايشگاهى يا تيمار با سرم (Y/4.4

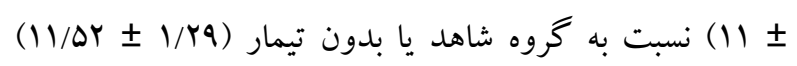

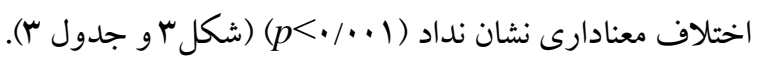

به گونهاى كه ميانگين تعداد اين سلولها در گروه تجربى r (Y \pm I/AY (YN/DY \pm ( G/YF) نسبت به كروههاى شاهد يا كنترل منفى (·r/Y I

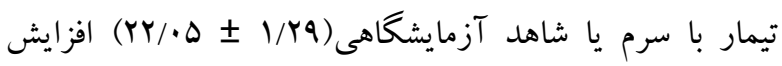
معنادارى نشان داد (هـ/ • >م). در روز هفتم ميانگين تكثير سلولهاى التهابى در اكثر كروهها، بِ يساز اينكه به ماكزيمم تراكم رسيده بودند، كاهش يافت، با اين وجود در اين روز بين كروههاى مورد مطالعه اختلاف معنىدارى مشاهده نشد (هـ/

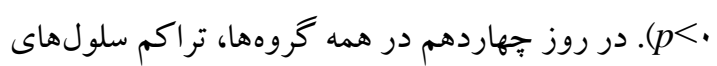




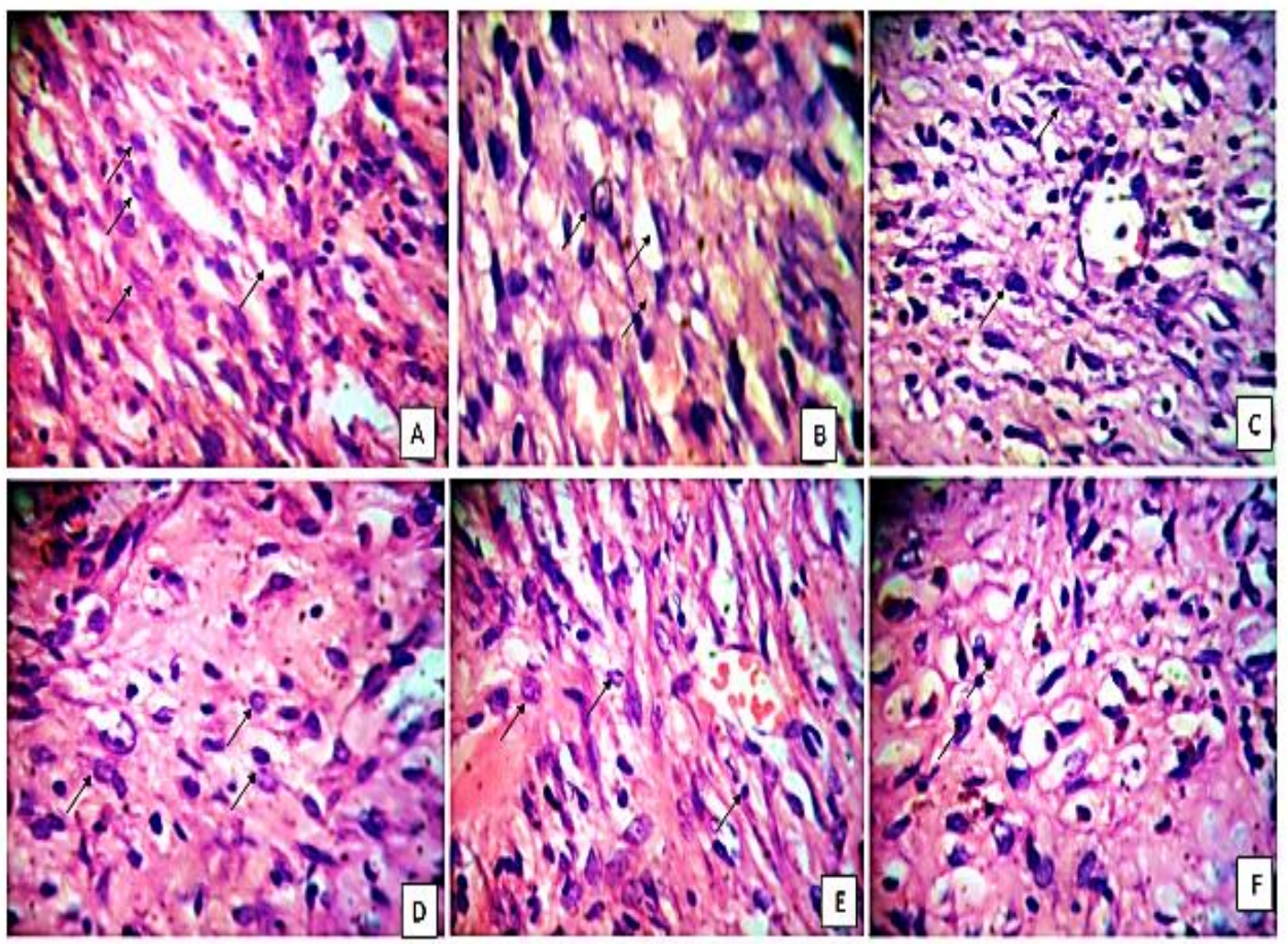

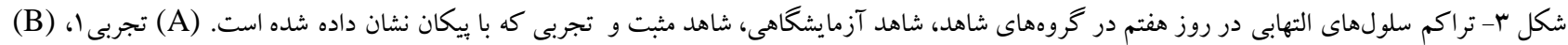

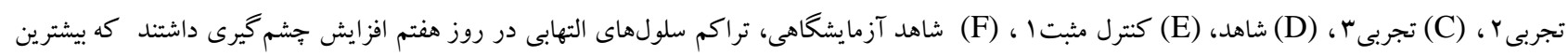

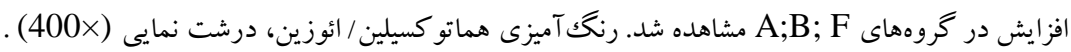

Fig. 3. The density of inflammatory cells on the seventh day of treatment in the control, sham, positive control and experimental groups which is shown with arrows. (A)Experimental 1, (B) Experimental 2, (C) Experimental 3, (D) control, (E) positive control 1, (F) sham, which indicated the highest density of inflammatory cells on the seventh day in group A; B ; F. Magnification 400x.

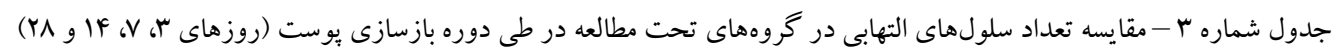

Table 3. Comparison the number of inflammatory cells in the experimental groups during skin regeneration period (3, $7,14,28$ days).

\begin{tabular}{|c|c|c|c|c|c|c|c|}
\hline & شاهد & سرم & عسل & $\Delta . \%$ & $\mathrm{~V} \Delta \%$ & $1 . . \%$ & $p$ \\
\hline سلول التهابى روز r & $r r / r \Delta \pm r / r$. & $r Y / \cdot \Delta \pm 1 / r q$ & $M \pm 1 / \Lambda r$ & $r F / \Delta \pm Y / \cdot \Lambda$ & $r G / \Delta r \pm|N|$ & $r N / D T \pm 9 / Y F$ & . For \\
\hline سلول التهابى روز V & $r Y / \Delta \pm r / \cdot \Lambda$ & $Y / N \Delta \pm 1 / Y q$ & $r \Delta \pm \cdot / \Lambda)$ & $r T / r \Delta \pm Y / r r$ & $r F / \Delta \pm r / \cdot q$ & $r \Delta N \Delta \pm 9 / .9$ & .19 .9 \\
\hline سلول التهابى روز IF & $r \cdot / \Delta \pm Y / \Lambda \Lambda$ & $M|\Delta \pm| N \mid$ & $1 r \pm r / 19$ & $|9 / \Delta r \pm Y M|$ & $1 \Delta / \Delta \pm r / 9 \Delta$ & $|r / \Delta r \pm| M \mid$ & $\cdot \cdots$ \\
\hline سلول التهابى روز YN & $11 / \Delta r \pm 1 / r q$ & $\mid r / N \Delta \pm Y / \cdot 9$ & $M T \pm 1 / A r$ & $11 \pm 1 / \lambda r$ & $N T \Delta \pm r / r$. & $V / \Delta \pm 1 / \% q$ & $\% \cdots$ \\
\hline
\end{tabular}

$$
\begin{aligned}
& \text { گروههاى تجربى Y و ب و تيمار با عسل مشاهده شد. در روز } \\
& \text { هفتم ميانگين تراكم عروق در همه گروهها افزايش يافت كه اين }
\end{aligned}
$$

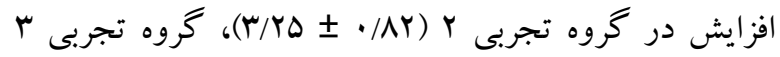

$$
\begin{aligned}
& \text { (F/10 }
\end{aligned}
$$$$
\text { > معنى دار بود (شكل F) }
$$

\section{تحليل تعداد جوانههاى عروقى}

ميانگين تراكم عروق خونى در روز سوم آزمايش در گروههاى

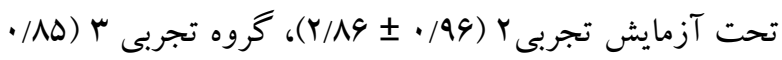

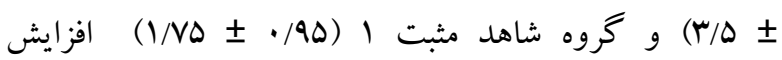
معنادارى در مقايسه با گروه شاهد يا بدون تيمار نشان داد

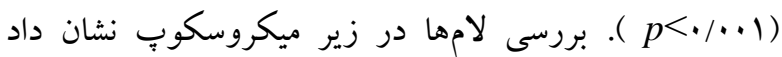

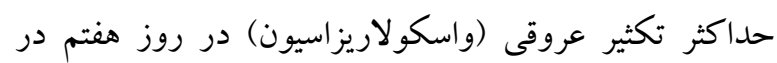



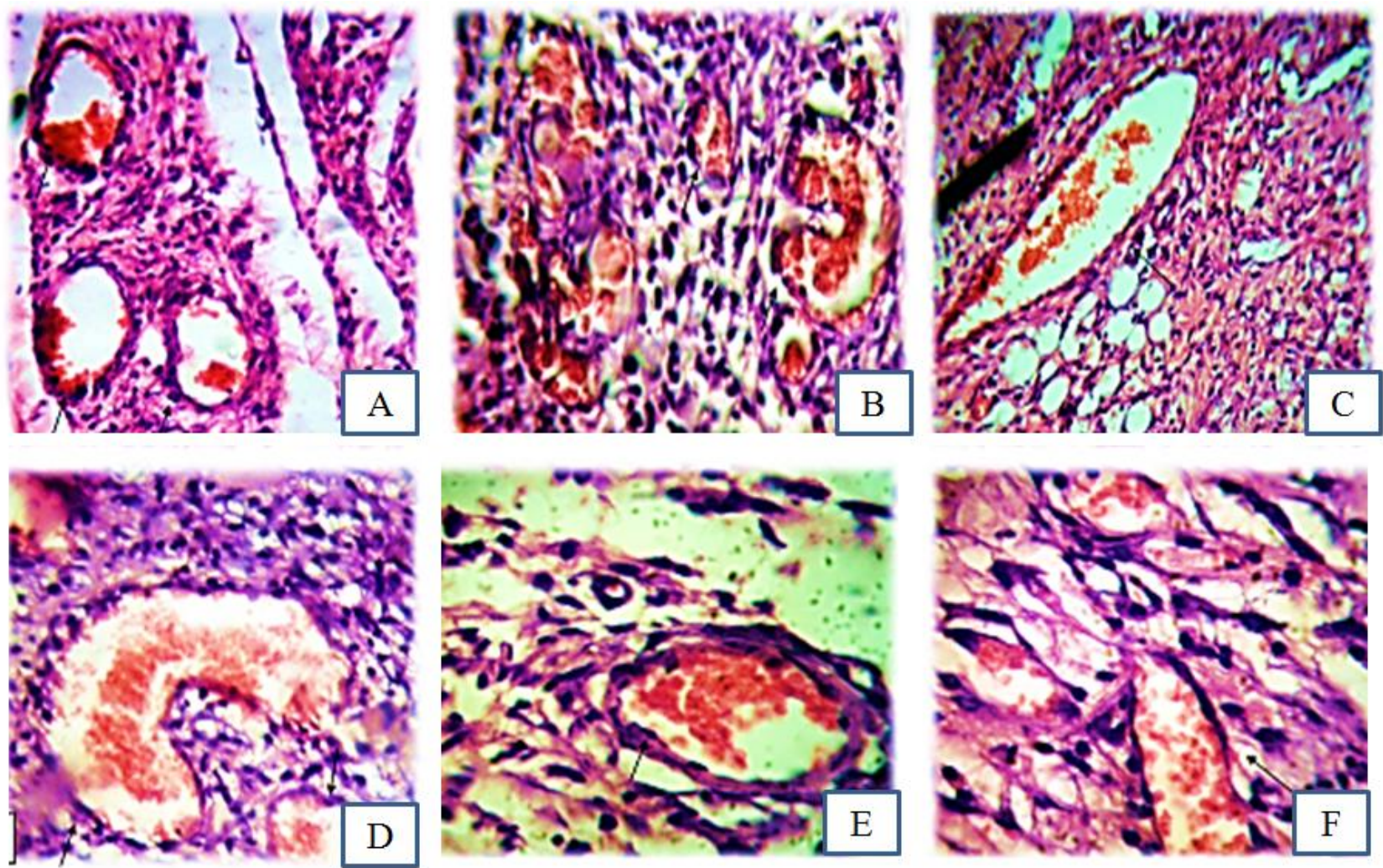

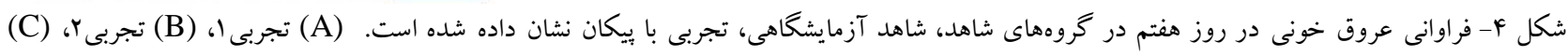

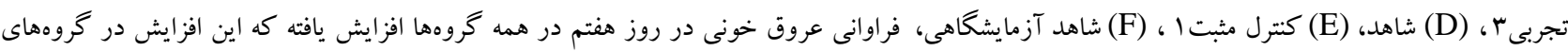

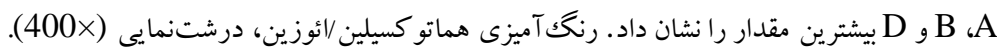

Fig. 4. Frequency of blood vessels on the seventh day of treatment in the control, sham, experimental groups which is shown with arrows. (A) Experimental 1, (B) Experimental 2, (C) Experimental 3, (D) control, (E) positive control 1, (F) sham, the number of blood vessels on the seventh day in all categories increased with highest rate in A, B and D groups. Magnification 400x

جدول F- مقايسه تعداد جو انه هاى عروقى در گروههاى تحت مطالعه در طى دوره بازسازى يوست (روزهاى بـ و V).

Table 4. Comparison the number of blood vessels in the experimental groups during skin regeneration period (3, 7

\begin{tabular}{|c|c|c|c|c|c|c|c|}
\hline & شاهد & سرم & عسل & $\Delta . \%$ & V $\Delta \%$ & $1 \ldots \%$ & $p$ \\
\hline عروق خونى روز r & $r \pm \cdot / \wedge r$ & $1 / \wedge \Delta \pm \cdot / 94$ & $r / V \Delta \pm \cdot / 9 \Delta$ & $r / \cdot \Delta \pm \cdot / 9 q$ & Y/A9 $\pm \cdot / 99$ & $\Gamma / \Delta \pm \cdot / \wedge \Delta$ & $\cdot 11 \cdot 1$ \\
\hline عروق خونى V & $r / Y \Delta \pm \cdot / 99$ & $r \pm \cdot / 99$ & $F / \cdot V \pm \cdot / \Lambda \mid$ & $r / \Delta \pm 1 / r q$ & $r / r \Delta \pm \cdot / A r$ & $4 / 10 \pm \cdot / 94$ &.$/ . \cdot F$ \\
\hline
\end{tabular}

تحليل تعداد سلولهاى فيبروبلاستى

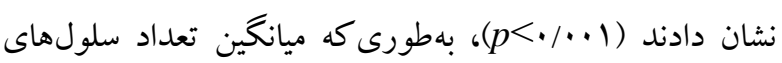
فيبروبلاستى در همه گروهها به حداكثر ميزان خود رسيد. در دراند

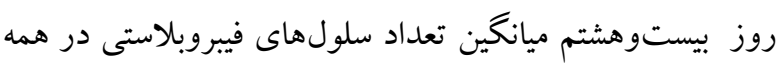

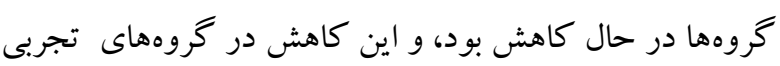

ا

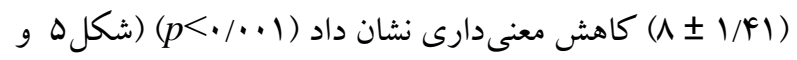

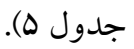

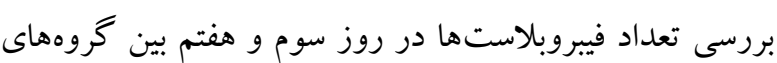

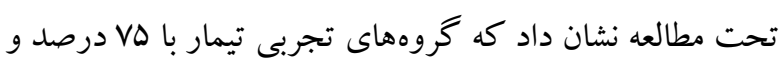

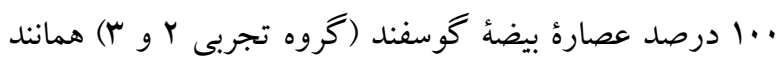

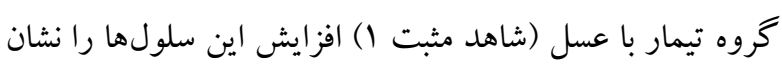

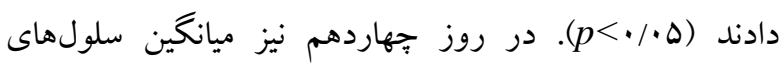

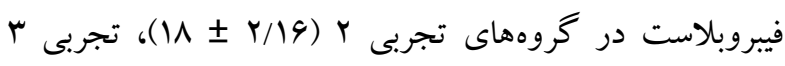

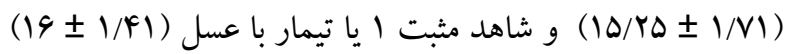

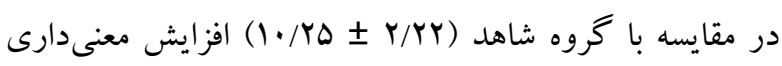



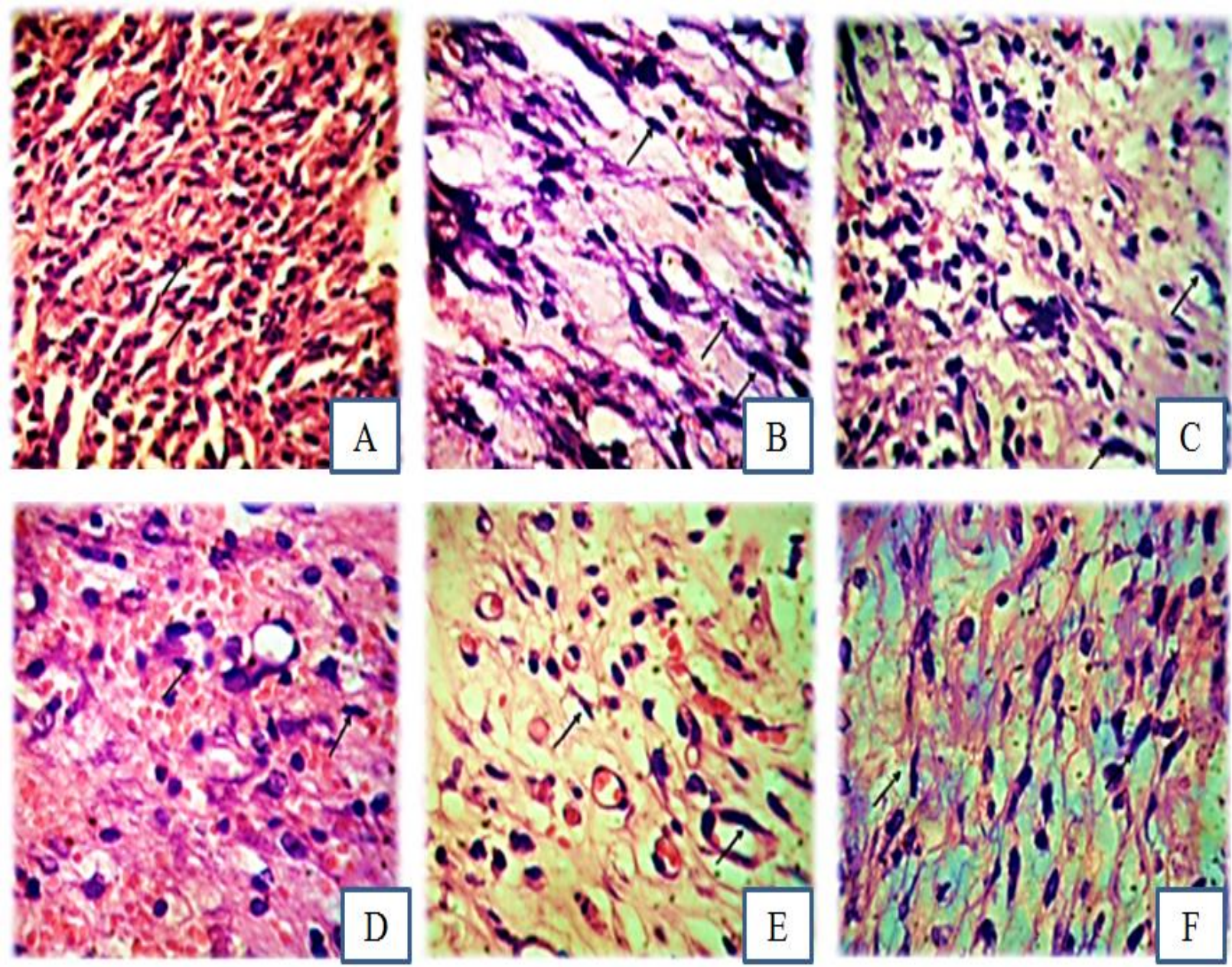

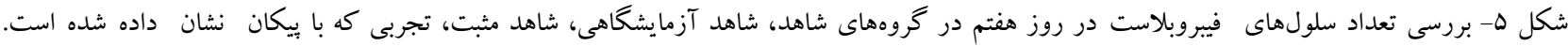

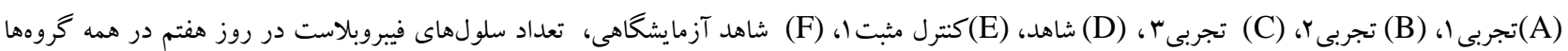

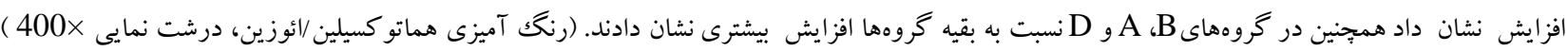

Fig. 5. Evaluation of fibroblast cell number in the seventh day of treatment in the control, sham, positive control and experimental groups which is shown with arrows. A) Experimental 1, (B) Experimental 2, (C) Experimental 3, (D) control, (E) positive control 1, (F) sham, the number of fibroblasts in the seventh day in all groups showed elevation but groups D, A and B showed more increment rther than another groups. Magnification 400x.

بهدليل معرفى نشدن دارويى قطعى براى بهبود روند ترميم زخم و رشد فوليكول مو، مطالعات بسيارى دربارهُ مواد طبيعى و تأثير آن بر رشد فوليكول مو و روند ترميم زخم صورت گرفته است (Toyoshima et al., 2012). در اين يُزوهش نيز با توجه به خواص آندروزنها و فاكتورهاى رشد موجود در بيضة كوسفند و نقش بيولوزيك آنها، تأثير آن بر زخمهاى يوستى و رشد فوليكول مو در موش صحرايى نر نزاد ويستار تحقيق شده است و ضخامت إيدرم، سلولهاى التهابى، فيبروبلاستها، سلولهاى بازال، عروق و فوليكول مو تحت بررسى قرار گرفته است.

$$
\begin{aligned}
& \text { مو در روزى سوم و هفتم فوليكولهاى موليكول مو بهوسيلة ميكروسكوبِ نورى }
\end{aligned}
$$

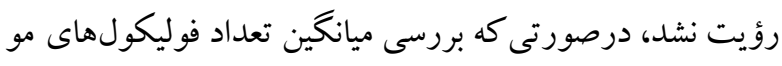

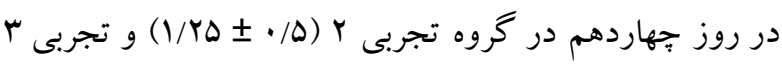

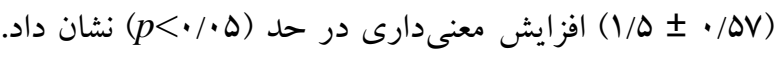

$$
\begin{aligned}
& \text { در روز بيستوهشتم افزايش تعداد فوليكول مو در تمام گروهها }
\end{aligned}
$$

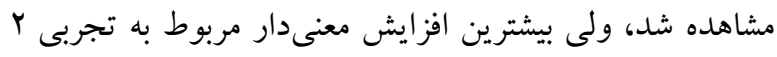

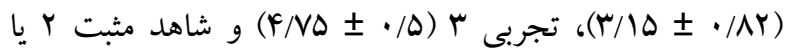

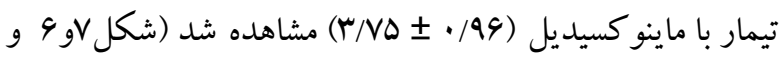



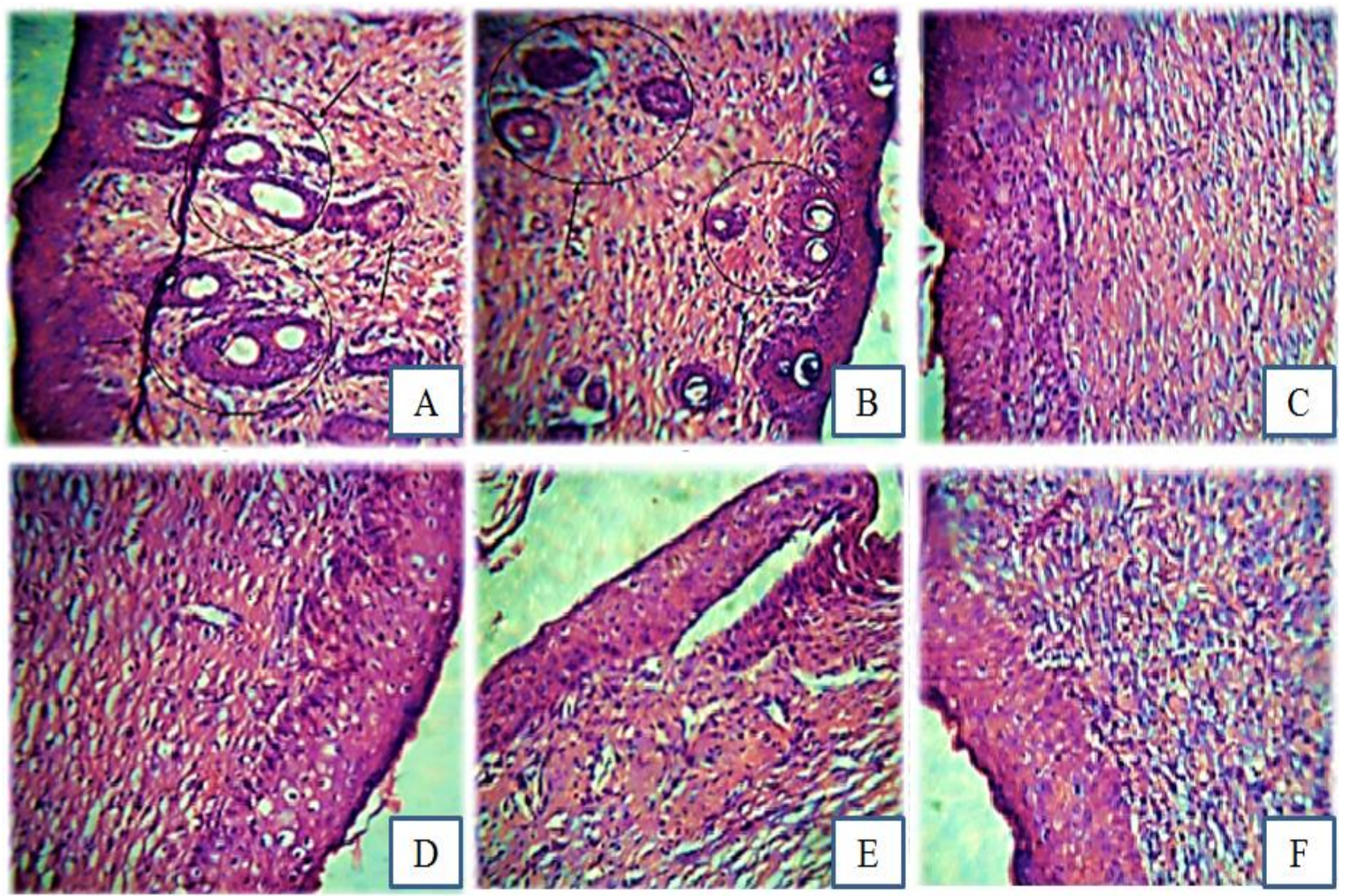

شكل 9- بررسى ييدايش فوليكول مو در روز جهاردهم در گروههاى شاهد، شاهد آزمايشگاهى، شاهد مثبت و تجربى كه در مركز دايره مشخص شده است. همان-

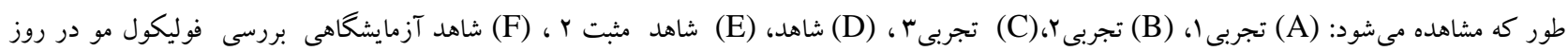

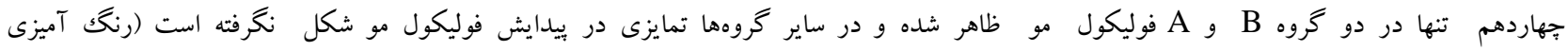

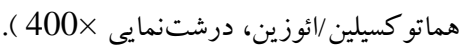

Fig. 6. Investigating the appearance of hair follicles on the fourteenth day of treatment in control, sham, positive control and experimental groups which are indicated in the center of the circle. A) Experimental 1, (B) Experimental 2, (C) Experimental 3, (D) control, (E) and positive control 2, (F) sham. As shown, hair follicles were observed on the fourteenth day in groups A \& B and no hair follicle have formed in other groups. Magnification 400x.

$$
\text { جدول شماره 4- مقايسه تعداد فوليكول مو در گروههاى تحت مطالعه در طى دوره بازسازى يوست (روزهاى If او (Y ) }
$$

Table 6. Comparison the number of hair follicles in the experimental groups during skin regeneration period (14, 28 days).

\begin{tabular}{|c|c|c|c|c|c|c|c|c|}
\hline & 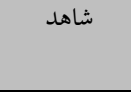 & عسل & 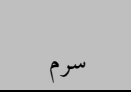 & ماينو كسيديل & $\Delta . \%$ & vQ $\%$ & $1 \ldots \%$ & $p$ \\
\hline فوليكول مو روز If & . & . & . & . & . & $1 / r \Delta \pm \cdot / \Delta$ & $1 / \Delta \pm \cdot / \Delta V$ &.$/ . r$. \\
\hline فوليكول مو روز & $r / \Delta \pm \cdot / 91$ & $r / Y \Delta \pm \cdot / 9 \varphi$ & $r / r \Delta \pm \cdot / \Delta$ & $r / V \Delta \pm \cdot / 99$ & $r / \Delta \pm 1 / r q$ & $r / \Lambda \Delta \pm \cdot / \Lambda r$ & $F / v \Delta \pm \cdot / \Delta$ & $\cdot / \cdots$ \\
\hline
\end{tabular}

آندوتليوم و ميزان رگكزايى سنجيده شده است و ازطريق

بررسى اين شاخصها روند ترميم و بهبودى زخم ازلحاظ بافت

شناسى ارزيابى شده است (Suntar et al., 2010).
در مطالعات گوناگونى كه در زمينهُ تأثير تركيبات مختلف در بررسى روند ترميم زخم صورت گرفته است، شاخصهايى

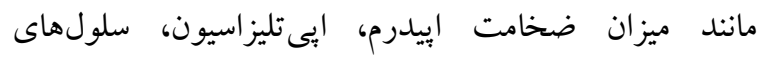
ماكروفازى، لنفوسيت، فيبروبلاست، نوتروفيل، عروق خونى، 

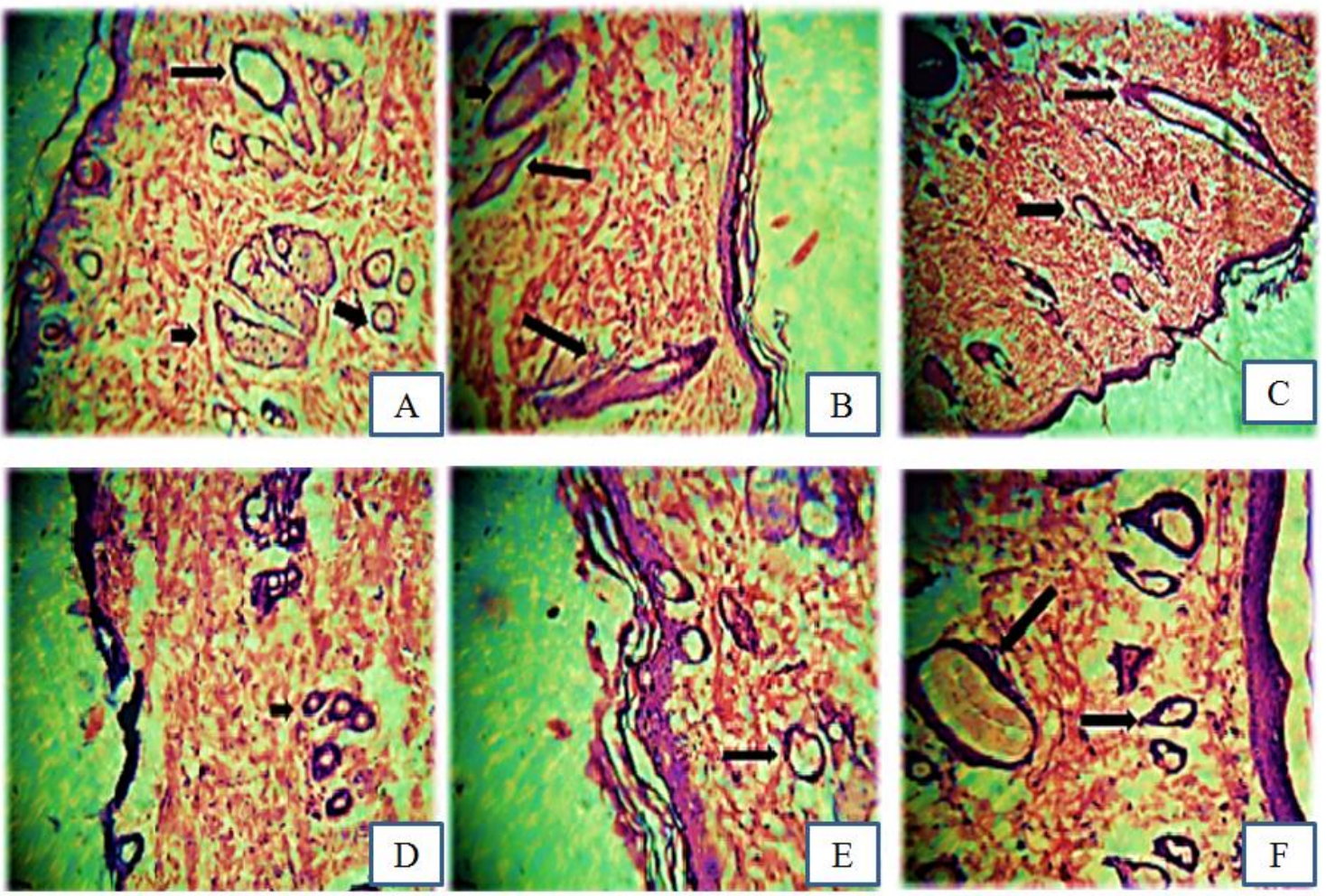

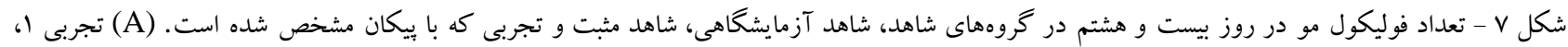

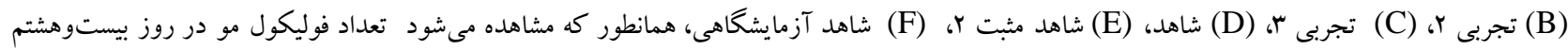

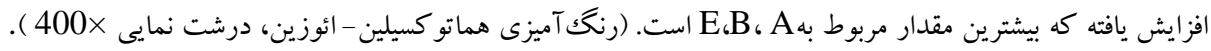

Fig.7. The number of hair follicles in the twenty-eighth day of treatment in the control group, sham, positive control and experimental groups which marked with arrows. (A) Experimental 1, (B) Experimental 2, (C) Experimental 3, (D) control, (E) and positive control 2, (F) sham, as shown, the number of hair follicles were increased in the twenty-eighth treatment period with highest rate in A, B, E . Magnification 400×

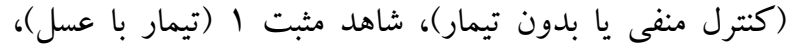
شاهد مثبت r (تيمار با ماينو كسيديل)، شاهد آزمايشگاهى (تيمار با سرم فيزيولوزيكك)، گروه تجربى ا (تيمار با عصاره

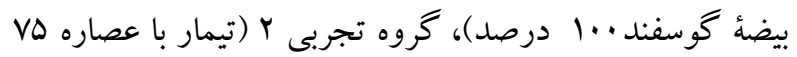
درصد) و گروه تجربى ץ ( تيمار با عصاره •ه درصد)، در روز سوم در مساحت زخم افزايش نشان دادند كه اين افزايش مساحت در روزهاى آغازين مطالعه بهواسطة تطابق زمانى با فاز

التهابى ترميم توجيه بذير است (Rezaii et al., 2008). جنان كه از ارزيابى آمارى نيز برمى آيد، ميزان تراكم منطقهاى در كروههاى آزمون بهتدريج افزايش يافت و در روز هفتم به بيشترين مقدار خود رسيد كه در اين روز افزايش لايهها نيز مشاهده شد. بيشترين مقدار تراكم منطقهاى در كروه تجربى 1 (تيمار با عصاره . ․ درصد ) مشاهده شد، درصورتى كه در بقئ
در اين بزوهش، از آنجايى كه مطالعات نشان دادهاند كه عسل بهدليل دارا بودن ويتامينهايى نظير تيامين، نياسين، ريبوفلاوين، يانتونيكاسيد، و همجنين مواد معدنى شامل كلسيم، آهن، منيزيم، منگنز، فسفر، يتاسيم، سديم، روى و تركيبات آنتىاكسيدان شامل كرايزين، ويتامين C وكاتالاز داراى اثر ترميم زخم جشم گيرى است (Jull et al., 2008)، بهمنزله شاهد مثبت ا در بررسى روند ترميم زخم و ماينو كسيديل به دليل دارا بودن اثر مثبت در روند شكل گيرى فوليكول مو ( Messenger

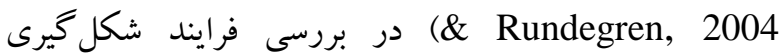
فوليكول مو به مثابة شاهد مثبت r مورد استفاده قرار كرفت. در مطالعهُ حاضر نيز فاكتورهايى ازقبيل ايىتليزاسيون، تعداد سلولهاى التهابى، ميزان عروق خونى، سلولهاى فيبروبلاستى، فوليكولهاى مو و سلولهاى بازال هدف ارزيابى قرارگرفت. همانطور كه در بخش نتايج گزارش شد، هفت گرووه شاهد 
مبنى بر بازسازى إيدرم تحت تاثير عصاره بيضه كوسفند در طى

ترميم زخم تطابق دارد (Guo \& DiPietro, 2010).

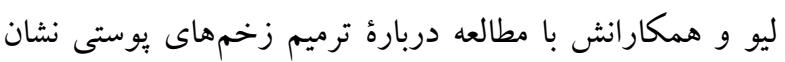

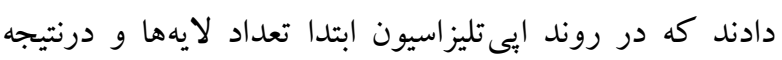
تراكم منطقهاى در ناحية آسيبديده افزايش مى يابد كه در اين

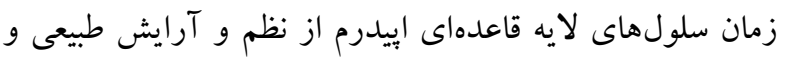

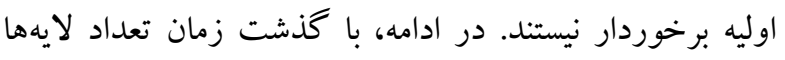
كمتر مىشود و سلولها آرايش و نظم بيشترى به خود مى خيرند

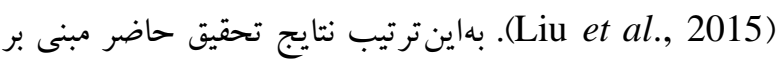
افزايش تراكم لايههاى سلولى و افزايش مسافتى كه سلولهاى

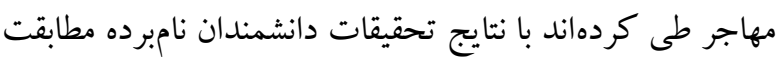

ويلكاس و جانسون در مطالعات خود در باب فرايند ترميم زخم، رگكزايى را يكى از سازو كارهاى بهبود زخم بيان كردند (Johnson \& Wilgus, 2014) عروق جديد از مويرگكهاى قبلى، باعث افزايش تغذيه بافت و

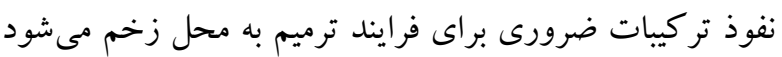

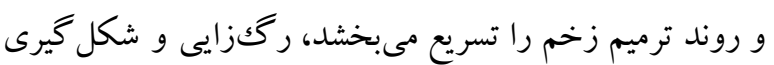

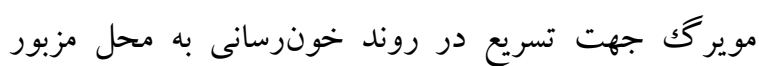
Bao et al., ) همراه با بيان فاكتور VEGF (2009

تييد در تحقيقات خود اندروزنها را شاخص حائز اهميت سيستميك كنترل در رشد مو دانست و نشان داد كه هورمونهاى

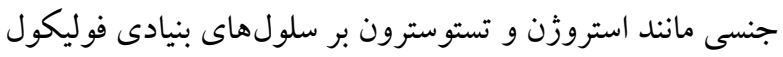

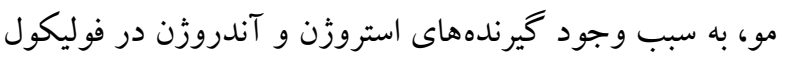
مو، اثر گذار هستند (Tiede et al., 2007). در بررسى يافتهاى اين يُزوهش نيز نشان داده شد كه عصارة

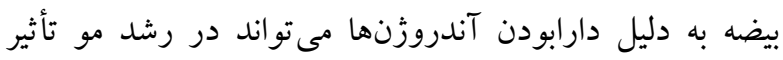

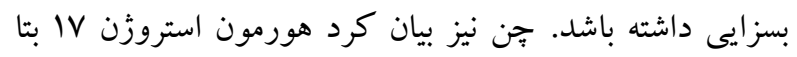

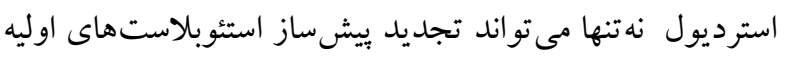

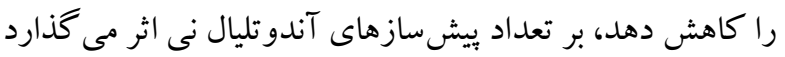
و آن را افزايش مى دهد تا بتو اند به سلولهاى غشاى درونى ركى و قلب تفكيك شود و ازطريق عمل كاسياز ه، اثر ضد آيويتوز و و ترميم رگكاى خونى آسيب ديده را افزايش دهد ( Chen et
كروهها تفاوت معنادارى مشاهده نشد. از روز هفتم به بعد، نيز به تدريج با گذشت زمان از ضخامت إيىتليوم كاسته شد. در دورة تحت مطالعه حداكثر تكثير سلولهاى التهابى در روز

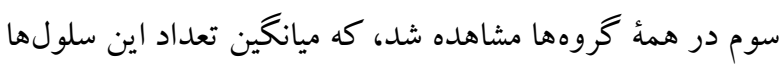

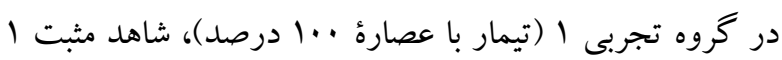
(تيمار با عسل) و شاهد در اين روز از خروههاى ديخر آزمون

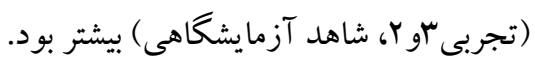

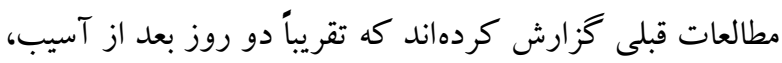

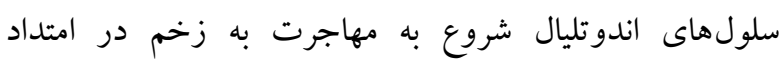

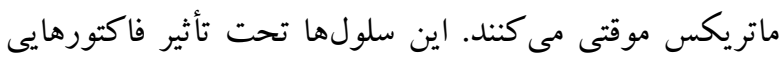
مثل فاكتور رشد اندوتليال عروق مهاجرت را انجام مىدهند و

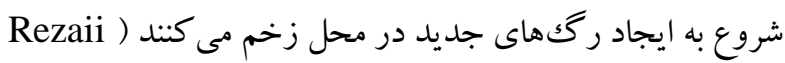

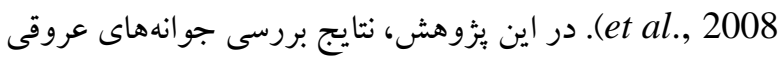
نشان داد كه حداكثر تكثير عروقى (واسكولاريزاسيون) در روز

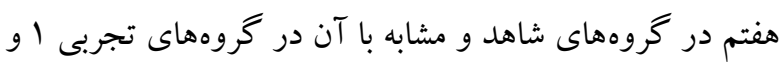
r مشاهل

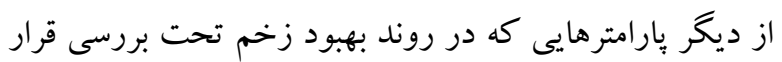

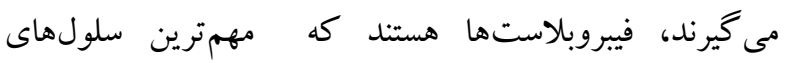
مز انشيمى در ترميم زخم بوده و داراى دو نقش عامل و و عمل كننده هستند. در نقش عامل، فيبروبلاستها كلازن پِيائ

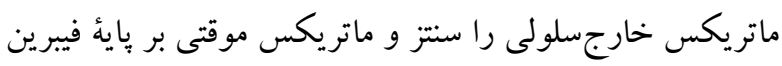

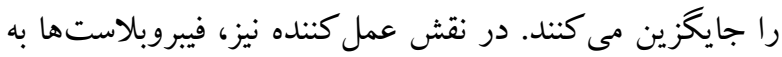

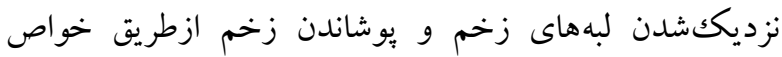

انقباضى خود كمك مى كنند (Guo \& DiPietro, 2010). فيبروبلاستهايى كه به مهاجرت ياسخ دادهاند و به ماتريكس

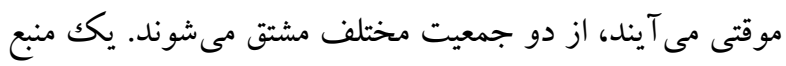

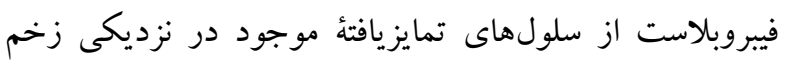

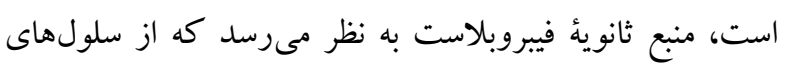

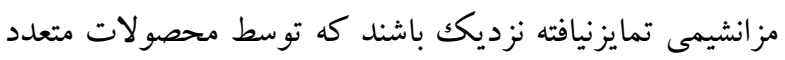

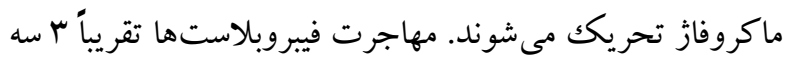
روز بعد از آسيب صورت مى يذيرد (Darby et al., 2014).

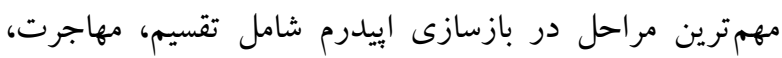

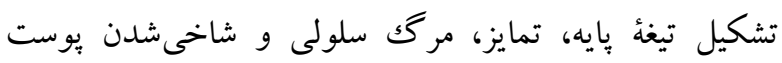
است، نتايج گيو و دى بترو تأييد مى كنند كه التيام زخم مرهون

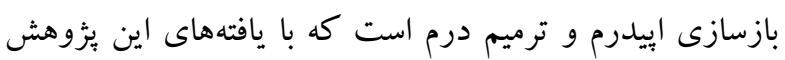


نقش مثبت اندروزذهاى درون بافت بيضه، فاكتورهاى رشد موجود در بيضه نيز در رشد فوليكولهاى موش صحرايى تحتتيمار با عصارةٔ بيضه عملكرد مهمى را برعهده دارند. هورمونها در بِاسخهاى سلولى و بافتى، مانند رشد فوليكول مو، افزايش التهاب و توليد بروتئين اثر مهمى در سرعت التيام و رشد فوليكول مو دارند (Ashcroft \& Mills, 2002). ازاينرو، با توجه به توانايى بيضه بهمنزلهُ منبعى از آندروزنها و فاكتورهاى رشد اميد دستيابى به منبع بىيايانى از تركيبات ترميم كننده افزايش مىيابد و شناسايى تركيبات مؤثر در آن نيز كه در بهبود زخم و كاهش قطع اندامها، افزايش رشد مو و ممانعت از ريزش مو مؤثر باشند مىتواند باعث بهبود كيفيت زندگى، كاهش هزينه هاى درمانى و كاهش استفاده از داروهاى شيميايى شود.

\section{نتيجه كيرى}

يافته هاى حاصل از اين بثزوهش تجربى نشان داد كه عصارهُ بيضهُ

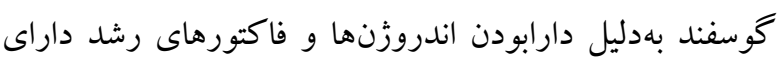
نقش مؤثرى در بهبود فرايند ترميم زخم و رشد فوليكول مو در موش صحرايى است. لذا بررسى اثر تركيبات مؤثر عصارهُ بيضهُ گوسفند با بكارگيرى تكنيك هاى مولكولى و تخليص مواد موثر در روند ترميم زخم و رشد فوليكول مو در مهندسى بافت

$$
\text { مى تواند حائز اهميت باشد. }
$$

\section{سياسگز ارى}

از همكاران محترم مركز تحقيقاتى بيولوزى كاربردى تكوين جانورى دانشگاه آزاد اسلامى مشهد كمال تشكر راداريم.

كليور، م.، ربانى، ح.، فرزين، د. و عزيزى، ف. بهrا. مقايسه

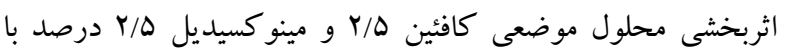

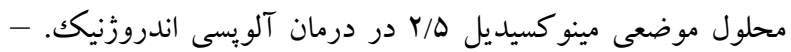

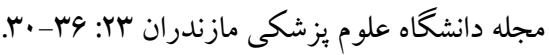

Ashcroft, G.S. and Mills, S.J. 2002. Androgen receptor-mediated inhibition of cutaneous wound healing. - J. Clin. Invest. 110: 615-624.
بررسى نتايج اين يزوهش نيز نشان داد كه عصارهُ بيضه بهدليل وجود مقادير بالاى آندروزنها موجب افزايش معنىدار ترميم ركتهاى خونى شده است. جون در اين پئوهش به كارگيرى عصارهُ بيضة كوسفند موجب افزايش معنىدار در تعداد فوليكول مو نسبت به ديكر گروهها شد، بس مىتوان گفت اثر مثبت عصارةٌ بيضهُ كوسفند بر رشد فوليكول مو، احتمالاً ازجملهُ دلايل اثربخشى در گروههاى تجربى ا و Y بوده است كه توانسته توليد و رشد فوليكول مو را افزايش دهد. درباب تأثير عوامل مختلف بر رشد فوليكول مو، مطالعات در بارهٔ تأثير عوامل مؤثر بر رشد فوليكولهاى مو نشان داد كه فاكتورهاى رشد در تنظيم مورفوزنز و رشد فوليكول مو دركيرند

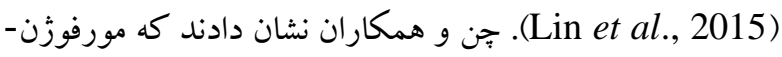
هاى مترشح فاكتور نكروز تومورى بر تعادل، رشد و ريزش مو اثر مى گذارند، اخرجّه بررسىهاى اخير روشن مى كنند كه سطوح متعدد كنترلهاى محيطى بر رشد مو وجود دارد ( Chen .et al., 2015 در اين ميان لين و همكاران (ها ·r) نشان دادند كه فاكتور رشد فيبروبلاستى با القاى فاز آنازن در فوليكولهاى مو موجب تسريع رشد فوليكولهاى مو مىشود و مى تو اند بتانسيل بالقوهاى بهمنزله Lin et al., ) عامل تسريع كنندهُ رشد فوليكول داشته باشد .(2015 بهعلاوه، مطالعات نشان دادهاند كه درون بافت بيضه فاكتورهاى رشدى مثل فاكتور رشد فيبروبلاستى، فاكتور رشد عصبى، فاكتور رشد إيدرمى و فاكتور رشد مبدل بتا وجود دارد كه بر مورفوزنز بافت بيضه مؤثر است و تحقيقات نشان داده است كه بر رشد و تكوين فوليكولهاى مو نيز مؤثر است ) Levine et al., 2000 ازاينرو مىتوان جنين نتيجه گرفت كه علاوهبر

\section{References / منابع} شيرزاد، ه.، صداقت، ا.، قاسمى، ث. و شيرزاد، م. هییזו. اثر زل رويال بر بهبود زخم ناشى از برش استريل در موش بالب سى.مجله ارمغان دانش ها:

Ashcroft, G.S. 2004. Sex differences in wound healing. - Adv. Mol. Cell. Biol. 34: 321-328.

Bates, K.A., Harvey, A.R., Carruthers, M. and Martins, R.N. 2005. Androgens, andropause and 
neurodegeneration: exploring the link between steroidogenesis, androgens and Alzheimer's disease. - Cell. Mol. Life. Sci. 62: 281-292.

Baum, C.L. and Arpey, C.J. 2005. Normal cutaneous wound healing: clinical correlation with cellular and molecular events. - Dermatol. Surg. 31: 674-686.

Chen, C.C. and Chuong, C.M. 2012. Multi-layered environmental regulation on the homeostasis of stem cells: The saga of hair growth and alopecia. $-\mathrm{J}$. Dermatol. Sci. 66: 3-11.

Chen, C.C., Wang, L., Plikus, M.V., Jiang, T.X., Murray. P.J. and Ramos, R. 2015. Organ-level quorum sensing directs regeneration in hair stem cell populations. - Cell 161: 277-290.

Conrad, S., Renninger, M., Hennenlotter, H., Wiesner, T., Just, L. and Bonin, M. 2008. Generation of pluripotent stem cells from adult human testis. - Nature 456: 344-349.

Darby, I.A., Laverdet, B., Bonté, F. and Desmoulière, A. 2014. Fibroblasts and myofibroblasts in wound healing. - Clin. Cosmet. Investig. Dermatol. 7: 301-311.

Dyce, P.W., Wen, L. and $\mathbf{L i}$, J. 2006. In vitro germline potential of stem cells derived fromfetal porcine skin. - Nat. Cell. Biol. 8: 384-390.

Eisenegger, C., von Eckardstein, A., Fehr, E. and Von Eckardstein, S. 2013. Pharmacokinetics of testosterone and estradiol gel preparations in healthy young men. - Psychoneuroendocrinology 38: 171178.

Golshan, A., Amini, E., Emami, S.A., Asili, J., Jalali, Z. and Sabouri Rad, S. 2016. Cytotoxic evaluation of different fractions of Salvia chorassanica Bunge on MCF-7 and DU 145 cell lines. - Res. Pharm. Sci. 11: 73-80.

Guo, S. and DiPietro, L.A. 2010. Factors Affecting Wound Healing. - J. Dent. Res. 89: 219-229.

Jaks, V., Kasper, M. and Toftgard, R. 2010. The hair follicle: a stem cell zoo. - Exp. Cell Res. 316: 1422-1428.

Johnson, K.E. and Wilgus, T.A. 2014. Vascular endothelial growth factor and angiogenesis in the regulation of cutaneous wound repair. - Adv. Wound Care. 3: 647-661.

Jull, A.B., Rodgers, A. and Walker, N. 2008. Honey as a topical treatment for wounds. -Cochrane Database Syst. Rev. 8: 41-48.
Léguillier, T., Lecsö-Bornet, M., Lémus, C., Rousseau-Ralliard, D., Lebouvier, N. and Hnawia, E. 2015. The Wound Healing and Antibacterial Activity of Five Ethnomedical Calophyllum inophyllum Oils: An Alternative Therapeutic Strategy to Treat Infected Wounds. PLoS One. 10: 1-20.

Levine, E., Cupp, A.S., Miyashiro, L. and Skinner, M.K. 2000. Role of transforming growth factor-alpha and the epidermal growth factor receptor in embryonic rat testis development. - Biol. Reprod. 62: 477-490.

Lin, W.H., Xiang, L.J., Shi, H.X., Zhang, J., Jiang, L.P. and Cai, P.T. 2015. Fibroblast Growth Factors Stimulate Hair Growth through $\beta$-Catenin and Shh Expression in C57BL/6 Mice. -Bio. Med. Res. Int. 201: 1-9.

Liu, J.Q., Zhao, K.B., Feng, Z.H. and Qi, F.Z. 2015. Hair follicle units promote re-epithelialization in chronic cutaneous wounds: A clinical case series study. - Exp. Ther. Med. 10: 25-30.

Messenger, A.G. and Rundegren, J. 2004. Minoxidil: mechanisms of action on hair growth. Br. J. Dermatol. 150: 186-194.

Okita, K., Ichisaka, T. and Yamanaka, SH. 2007. Generation of germline-competent induced pluripotent stem cells. - Nature 448: 313-317.

Pazyar, N., Yaghoobi, R., Rafiee, E., Mehrabian, A. and Feily, A. 2014. Skin wound healing and phytomedicine: a review. - Skin Pharmacol. Physiol. 27: 303-310.

Rezaii, A., Deazar, A., Mohajeri, D. and Taghizadeh Jahed, M. 2008. Effect of Echinacea purpurea herbal extract versus zinc oxide in rat skin wound healing model, histometric and histopathologic study. - Pharmaceutical. Sci. 74: 4352.

Sarabahi, S. 2012. Recent advances in topical wound care. - Indian J. Plast. Surg. 45: 379-387.

Sato, T., Katagiri, K., Gohbara, A., Inoue, K., Ogonuki, N., Ogura, A., Kubota, Y. and Ogawa, T. 2011. In vitro production of functional sperm in cultured neonatal mouse testes. - Nature 471: 504-507.

Suntar, I., Tatli, I.I., Kupeli Akkol, E., Keles, H., Kahraman, Ç. and Akdemir, Z. 2010. An ethnopharmaclogical study on Verbascum species : from conventional wound helaing use to scientific verification. - J. Ethnopharmacol. 132(2): 408-413. 
Tiede, S., Kloepper, J., Bodo`, E.,Tiwari, S. Kruse, C.and Paus, R.2007.Hairfollicle stem cells: Walking the maze. - Eur. J. Cell Biol. 86: 355-376. Toyoshima, K.E., Asakawa, K., Ishibashi, N.,
Toki, H., Ogawa, M. and Hasegawa, T. 2012. Fully functional hair follicle regeneration through the rearrangement of stem cells and their niches. Nat. Commune. 3: 1-12.

Sohrabifar, N., Baharara, J., Mahdavi Shahri, N., Zafar Balanejad, S. and Amini, E. 2016. The impact of sheep testis extract on hair follicle growth and skin healing of Wistar rats. - Nova Biol. Rep. 3: 24-38.

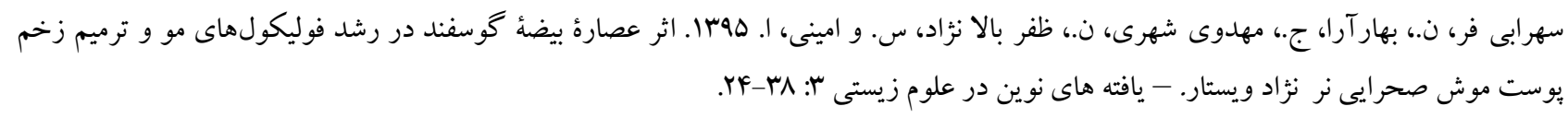

